Linköping Studies in Science and Technology

Dissertations, No.1675

\title{
On Service Innovation and Realization in Manufacturing Firms
}

Per Carlborg

Department of Management and Engineering Linköpings universitet, SE-581 83 Linköping, Sweden 
(C) Per Carlborg, 2015, Unless otherwise noted

On Service Innovation and Realization in Manufacturing Firms

Linköping Studies in Science and Technology, Dissertations, No. 1675

ISBN: 978-91-7519-053-2

ISSN: 0345-7524

Printed by: LiU-Tryck, Linköping

Distributed by:

Linköping University

Department of Management and Engineering

SE-581 83 Linköping, Sweden

Tel: +46 13281000 
In memory of my brother

Erik Carlborg 


\section{ABSTRACT}

Service innovation is increasingly becoming a basis for manufacturing firms to reach and sustain competitive advantages. While traditional product innovation typically includes how new technology can be utilized in new products, service innovation spans a broader area that is not exclusively focused on new technology, but rather how resources can be developed into value propositions and then integrated in the customer's process in order to support customer value creation through realization. However, manufacturing firms that infuse services struggle with service innovation; this becomes especially evident in the realization phase.

This thesis is a compilation of five papers discussing different aspects of service innovation realization and the inherited challenges. The study builds upon empirical data from four Swedish manufacturing firms that infuse services and develop new value propositions that include both products and services to support customer processes. Interviews and workshops with managers and employees have been conducted in order to understand service innovation and realization.

The thesis illustrates realization as a phase in service innovation where the firm interacts with its customer in order to adjust, revise and further find new ways of improving the customer's processes through for example customer training. Realization is characterized by a deployment phase and a post-deployment phase that represent the ongoing relationship between the customer and the firm. Through this, the customer facing units (for example the field service organization) is dedicated a pivotal role in service innovation as these units have direct contact with the customer and also a relevant understanding of the customer's context.

As realization aims to improve the customer's value creating process, service productivity improvements for the customer, for example process optimization, is an interesting dimension in service innovation realization. This thesis outline modularity as a way to manage diverging customer needs in addition to efficiency requirement in the service innovation process, considering both firm and customer resources.

Depending on who has the competencies or ability to integrate the resources that are needed for service innovation, different interaction patterns are identified. Through indirect interaction, the firm facilitates the customer's value creation through, for example, preventive maintenance, while through direct interaction the firm acts as a co-creator in the service innovation process and hence work jointly together with the customer in order to improve customer value creation.

This thesis contributes to the literature by characterizing service innovation realization and by increasing the understanding for different interaction patterns and how the firm can act as a value co-creator in the service innovation process. 


\section{TJÄNSTEINNOVATION I TILLVERKNINGSFÖRETAG}

Satsningar på tjänsteinnovationer blir ett allt viktigare sätt för tillverkningsföretag att bibehålla och skapa nya konkurrensfördelar i takt med att konkurrensen från lågkostnadsländer ökar. Medan innovation i traditionell betydelse ofta beaktar hur ny teknologi kan användas i nya produkter för att sedan införas och kommersialiseras på en marknad, så innefattar tjänsteinnovation ett större område som inte är begränsat av ny teknologi utan snarare är inriktat på hur resurser av olika typer kan användas för att utveckla nya erbjudanden till kunden men även hur dessa kan integreras $i$ kundens processer i syfte att stödja de värdeskapande processerna som finns där. Emellertid har det visat sig svårt, särskilt för tillverkningsföretag, att arbeta med realiseringsfasen av tjänsteinnovation som framhåller stödjandet av kundens eget värdeskapande som en central del av tjänsteinnovationsprocessen. Framför allt eftersom den skiljer sig mycket från hur de traditionella innovationsprocesserna vanligtvis ser ut i tillverkningsföretag (internt fokuserade och inriktade på konkreta produkter). Detta riskerar att resultera i en situation där tillverkningsföretag utvecklar nydanande idéer och koncept som sedan erbjuds till kunder, men där sedan innovationsarbetet brister i stödjandet av kundens processer. Därmed riskerar kunden att inte kunna skapa värde utifrån vad som lovades i erbjudandet och företaget i sin tur kommer få svårt att vidmakthålla lönsamma tjänsteinnovationer.

Denna avhandling bygger på empiri från studier av fyra Sverige-baserade tillverkningsföretag som utvecklar kunderbjudanden som innefattar både produkter och tjänster. Intervjuer har varit den primära metoden att inhämta empiri, men även workshops, observationer och dokument har varit bidragit till att bygga upp och förstå de olika fallföretagen och tjänsteinnovationsprojekten. Intervjuer med kunder och återförsäljare har även genomförts för att få en bredare bild av tjänsteinnovationsprocessen. Då erbjudanden som kombinerar produkter och tjänster tenderar att bli allt viktigare för tillverkningsföretag generellt, lyfts förmågan till tjänsteinnovation upp som en viktig faktor kopplad till framgång. I takt med snabbt skiftande kundbehov blir dock tjänsteinnovation en stor utmaning för många tillverkningsföretag.

Denna studie har karaktäriserat och analyserat realisering som en fas av tjänsteinnovation där företag och kund interagerar och samverkar i syfte att anpassa, revidera och hitta nya sätt att förbättra kundens värdeskapande processer. Realiseringsprocessen karaktäriseras av genomförandet och även efter-genomförandet vilket representerar den, över tid, pågående relationen mellan kunden och företaget. Genom detta får fältserviceorganisationen hos företaget en viktig roll i tjänsteinnovation då denna enhet har den direkta kontakten med kunden och en god förståelse för kundens kontext. Beroende på vem som besitter kompetenser eller förmågor att integrera de resurser som krävs i tjänsteinnovationsprocessen, har olika interaktionsmönster i realiseringsfasen identifierats; genom indirekt interaktion kan företaget facilitera kundens värdeskapande genom till exempel förebyggande underhåll, och genom direkt interaktion kan företaget stödja kunden som en samskapare i tjänsteinnovationen och därmed arbeta tillsammans med kunden för att förbättra kundens värdeskapande. 


\section{ACKNOWLEDGEMENTS}

This book is the result of five years work at the department of Industrial marketing at Linköping University. Since writing a thesis sometimes can be a lonely work, I have appreciated all the interesting discussions with my colleagues. Your competencies and will to share your thoughts have vitalized my work.

First of all, I want to thank my supervisor Daniel Kindström for your support and engagement. During the whole process, you have encouraged me and brought joy to this PhD-journey. I really appreciate your commitment. Also in difficult times, you have kept your positive attitude.

My co-supervisor and co-author Christian Kowalkowski, thank you for your valuable comments and interesting discussions. Your support during these five years has been important for the writing of this thesis.

A special thanks to Fredrik Nordin since your critical reading has been very valuable in the finishing phases of both the licentiate thesis and this doctoral thesis.

To Vinnova (The Swedish Governmental Agency for Innovation System), for the funding of the two research projects that have been the base for this study. Also many thanks to MTC and all the involved firm representatives; Staffan, Jesper, Tor, Rene, Sture and Håkan for your commitment during the projects.

To all PhD students at IEl; during all our activities in the PhD network we have been able to discuss and forget about our problems together. Especially thanks my colleagues in the industrial marketingcorridor; being at work is easy with people like you. Daniel, Ya and Anders, thank you for great friendship during these five years. Hannah and Elisabeth, for all our interesting service-discussions and your laugh that fill up the corridor. Mario, Sarah, Maysam, Mojtaba, Ehsan and Martin, good luck with your writing, I'm looking forward to see the result.

To all my academic orienteering friends: Johan, Micke, Erik, Jerk, Peter, and Emil, and many more. I appreciate your company and the opportunity to discuss other aspects of life than research. Thank you for all the lunches, trainings, and Stafettvasan-journeys we have had together.

Finally, I would like to thank all my friends and my family. Without friends, life would be very poor. To my family for always being there with encouraging support. To see Sigrid grow up during the work with this thesis has been amazing. Nils and Margareta, I realize how lucky I am having you as father and mother.

Amélie, your love means everything to me and I hope to share the rest of my life with you.

Linköping, April, 2015

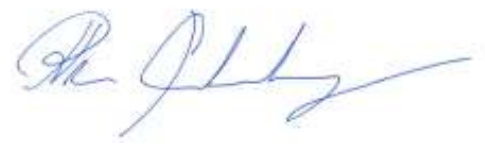

Per Carlborg 


\section{LIST OF ARTICLES}

I. The evolution of service innovation research - a critical review and synthesis, Carlborg, $\mathrm{P}$, Kindström, D., and Kowalkowski, C., 2014. The Service Industries Journal, Vol. 34 (5): 373398.

II. A lean approach for service productivity improvements - Synergy or oxymoron?, Carlborg, P., Kindström, D., and Kowalkowski, C., 2013. Managing Service Quality, Vol. 23(4): 291-304.

III. Service process modularization and modular strategies, Carlborg, P., and Kindström, D., 2014. Journal of Business and Industrial Marketing, Vol. 29 (4): 313-323.

IV. Triadic value propositions: When it takes more than two to tango, Kowalkowski, C., Kindström, D., and Carlborg, P., Submitted to Service Science, January 2015

V. Who involves Whom? Interaction modes in service innovation, Carlborg, P., Working paper. 


\section{MY CONTRIBUTIONS}

The thesis is built upon the research for five papers that I have both co-authored with colleagues and written alone. Below, I have notified my contribution to the papers with regard to research idea, research design, data collection, data analysis, synthesis, and writing up. I have been deeply involved in the papers since they have been an important part of this thesis.

I. Research idea, research design, data collection, data analysis, synthesis, and writing.

I constructed the research design and the research questions. Further, I did the literature search and cross-analysis and the synthesis of different phases in service innovation evolution. I also did the submission to the journal (SIJ) and served as the corresponding author. Together with my colleagues, I addressed revisions from the reviewers.

II. Research idea, research design, conceptual analysis, synthesis, and writing.

I developed the research concept and did the necessary literature review. Since it was a conceptual article, no data collection was initiated; however, the literature synthesis was my responsibility as well as the main part of writing for all the sections in the paper.

III. Research idea, research design, data collection, data analysis, synthesis, and writing.

I developed the research idea and, together with colleagues, and sometimes by myself, data was collected through interviews and focus groups. I transcribed interviews and also did the main part of the writing.

IV. Data collection, data analysis, and writing.

In this paper, the research design was partly already done as I entered the longitudinal study in a later stage. However, I conducted interviews which I transcribed and analyzed and then compared with earlier interviews. I also conducted observations and arranged workshops together with colleagues. For the writing, we divided the chapters among our three co-authors; my part was mainly to write the empirical part.

V. Research idea, research design, data collection, data analysis, synthesis and writing.

This paper has only one author; hence, I have done all the work with this paper. 


\section{TABLES AND FIGURES}

\section{Tables}

Table 1 Appended papers and their linkage to the research questions ............................................. 9

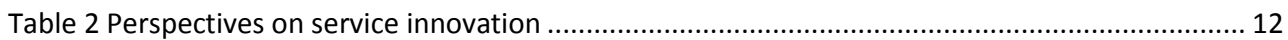

Table 3 Innovation types according to Gallouj \& Weinstein (1997) ................................................... 13

Table 4 Development and realization part of service innovation, adopted from Siltaloppi \& Toivonen (2015)

Table 5 Firm-centric and service logic approach to value creation and innovation ............................. 21

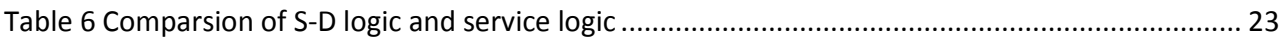

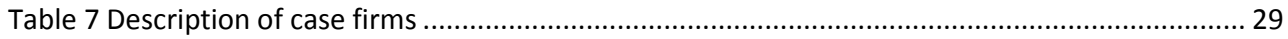

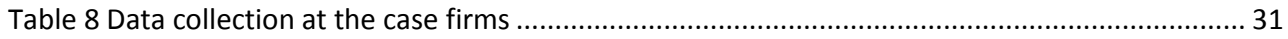

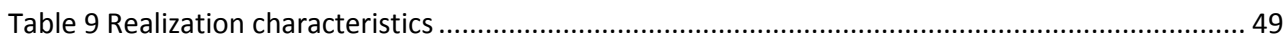

Table 10 Interaction for facilitating (indirect) and co-creation (direct) in service innovation.............. 54

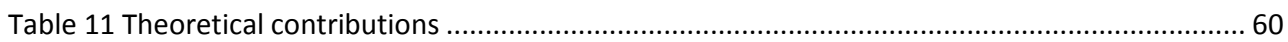

\section{Figures}

Figure 1 Service productivity model adopted from Grönroos and Ojasalo (2004) .............................. 20

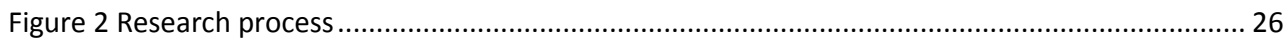

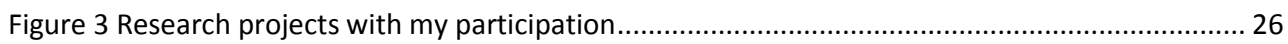

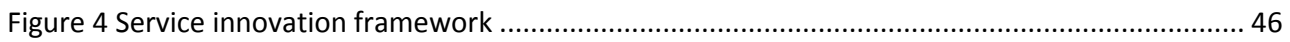

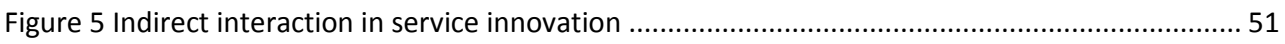

Figure 6 Direct interaction (value co-creation) in service innovation................................................ 52 


\section{TABLE OF CONTENTS}

1 INTRODUCTION

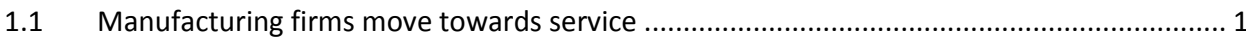

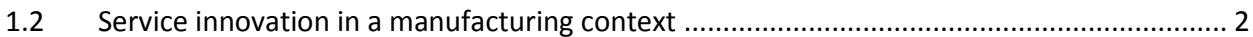

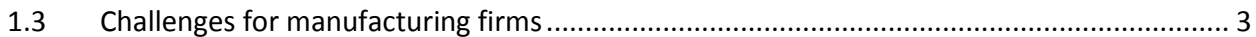

1.4 Exploring realization part in service innovation ................................................................ 4

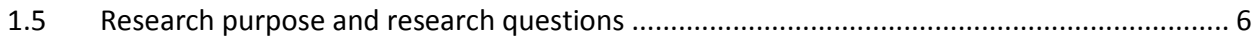

1.6 Contributions of papers and their linkage to the research purpose .................................... 8

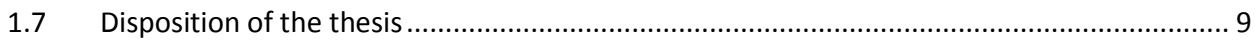

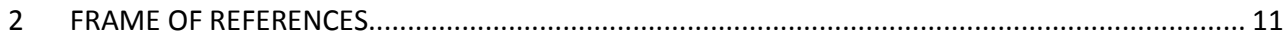

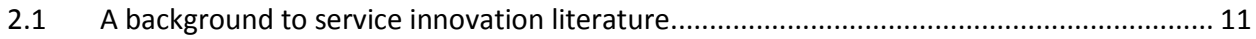

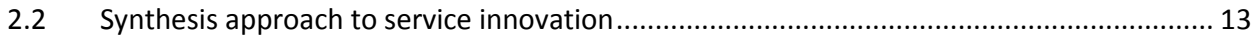

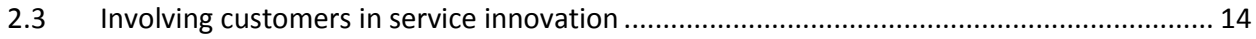

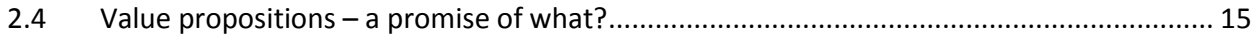

$2.5 \quad$ Realization as a an integral part of service innovation ........................................................ 16

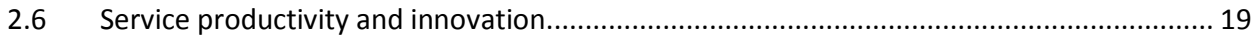

2.7 Service logic - an interactive approach to service innovation .......................................... 20

2.8 Summary of theoretical background and a base for further understanding ....................... 24

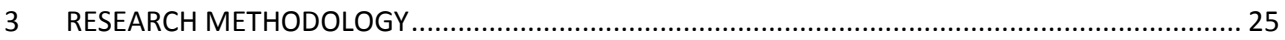

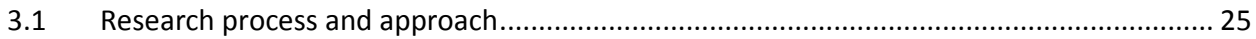

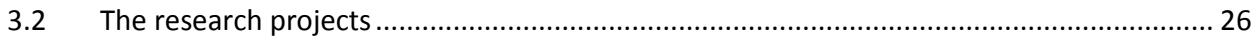

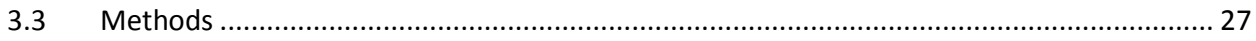

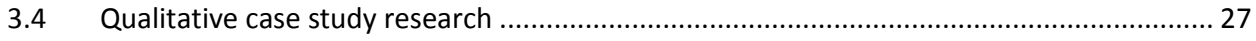

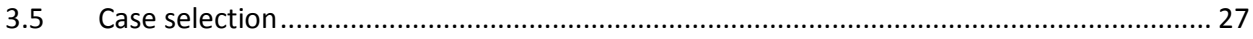

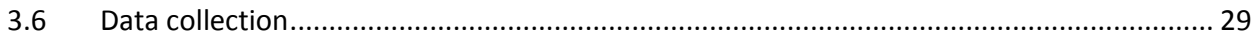




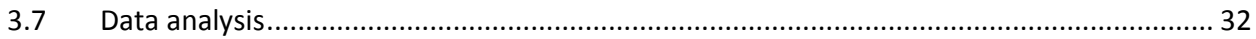

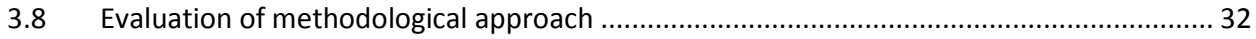

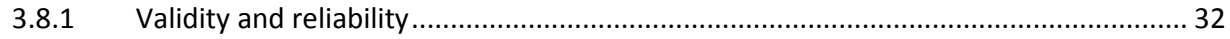

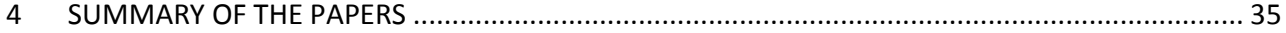

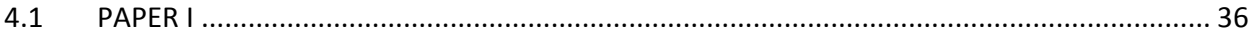

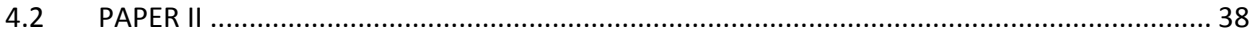

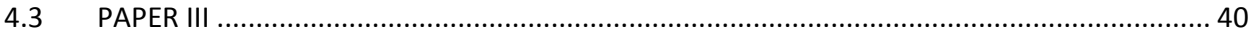

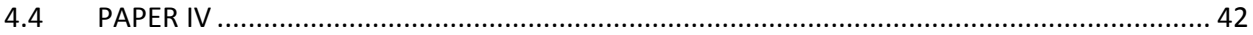

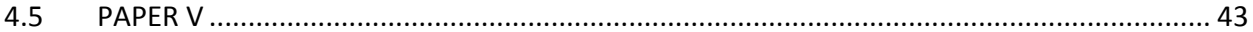

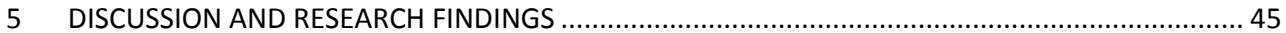

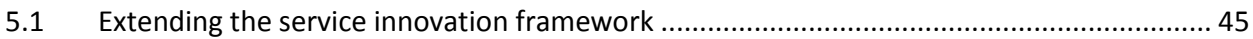

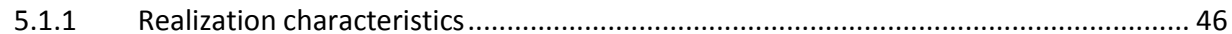

5.1.2 Productivity improvements as part of service innovation .......................................... 49

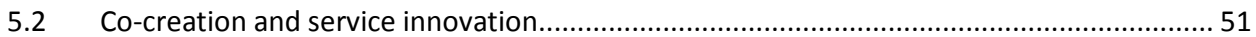

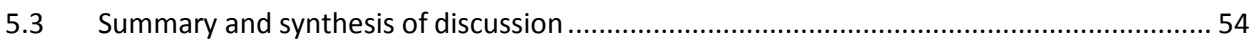

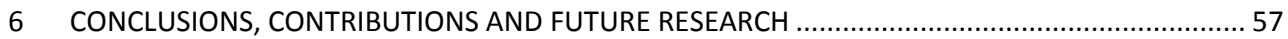

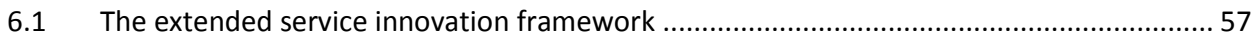

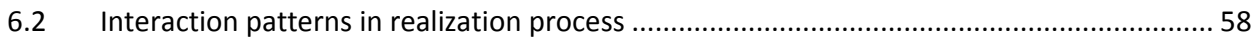

6.3 Understanding service productivity in realization part of service innovation .......................59

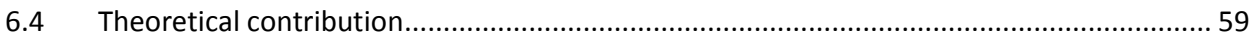

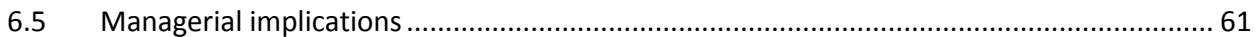

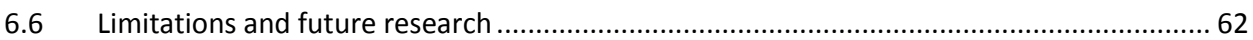

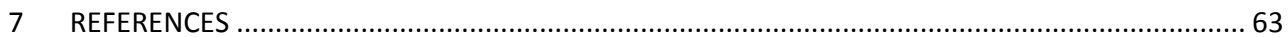




\section{INTRODUCTION}

\subsection{Manufacturing firms move towards service}

There comes a point of time when technology is so mature that it's very, very difficult to do a real innovation in technological terms... Companies, they start to think about that, well, but we have other types of innovations too, not just technological. (Vice president, Kone).

This quote from Kone (Salonen, 2011, p.686), a Finland-based manufacturer of elevators, escalators and automatic doors, illustrates how manufacturing firms with a traditional focus in product development and manufacturing start to expand their innovation focus to cover a broader range of innovation. Kone has redefined its business from a product manufacturer to a provider of people flow and access solutions which implies a greater interest in the customer's processes and how customers create value-in-use (Salonen, 2011). For Kone, revenues from services are more than $50 \%$ of total sales (Gebauer, Edvardsson, Gustafsson, \& Witell, 2010). The Kone-example shows that there are not only in traditional service sectors where services grows (e.g., transport, hotel, consultancy), also in manufacturing firms, service-led growth is seen as a business opportunity (Bessant \& Davies, 2007; Davies, 2004; Eggert, Hogreve, Ulaga, \& Muenkhoff, 2013; Gebauer, Ren, Valtakoski, \& Reynoso, 2012; Neu \& Brown, 2005; Ostrom et al., 2010; Sawhney, 2006). Increasingly, manufacturing firms add services to their already existing product-based offerings (Cova \& Salle, 
2008; Davies, 2004; Jacob \& Ulaga, 2008; Lindberg \& Nordin, 2008; Miles, 1993; Ulaga \& Reinartz, 2011). This development is undertaken for many reasons. Manufacturing firms are increasingly facing commoditization and declining profitability (Fang et al., 2008; Spring \& Araujo, 2013), and there is a belief that service and service-based strategies will improve firm competitiveness and growth (Antioco, Moenaert, Lindgreen, \& Wetzels, 2008; Ulaga \& Reinartz, 2011). For example, scholars indicate that services have higher margins than products (Anderson, Fornell, \& Rust, 1997), and a more stable source of revenue and more resistant against fluctuations compare with products (Quinn, 1992). Therefore, manufacturing firms develop offerings (and form value propositions that are reciprocal promises of value between firm and customer (Ballantyne \& Varey, 2006)) through for example pro-active maintenance, upgrades, performance-based contracts and consultant-services (Brax, 2005; Gebauer et al., 2012; Penttinen \& Palmer, 2007; Windahl \& Lakemond, 2010) and also involve the customer in the innovation process to identify current and future customer needs to develop offerings (Ettlie \& Rosenthal, 2011; Noordhoff, Kyriakopoulos, Moorman, Pauwels, \& Dellaert, 2011). Researchers suggest that innovation in general is becoming a major factor for a firm's competitiveness (Fitzsimmons \& Fitzsimmons, 1999), with service innovation being particularly advantageous (Bettencourt, Brown, \& Sirianni, 2012).

The shift for several manufacturing firms - from supplier and producer of goods, to service and cocreation of value together with customers - is not only a movement down the value stream, but also involves a combination of products and services (Brady, Davies, \& Gann, 2005; Davies, 2004; Sawhney, 2006; Ulaga \& Reinartz, 2011), which implies a wider offering to manage, and less of control since the manufacturer meet a situation where both firm and customer co-control how value is created for the customer (Strandvik, Holmlund, \& Edvardsson, 2012). For example, the Swedish telecom company Ericsson has increased its business to not only manufacture and deliver telecom equipment, but also being a system integrator that operates and maintains equipment in the customer's environment. The shift to increased service is not only driven by the manufacturing firm's chase for revenue, but also by customers' desire to take advantage of provider know-how that imply increase value-in-use (Vandermerwe, 1994) in (Kostecki, 1993). Hence, there are good reasons for a manufacturer to seek advantages by considering service and service innovation.

\subsection{Service innovation in a manufacturing context}

Innovation in manufacturing firms is traditionally understood as new technology, research and development (R\&D), design, and production with the aim of creating and commercializing products with new technology (Garcia \& Calantone, 2002; Gebauer et al., 2012). However, for service innovation in manufacturing firms, researchers argue that the process further include deployment and implementation activities (den Hertog, van der Aa, \& de Jong, 2010; Gebauer et al., 2012; Kindström \& Kowalkowski, 2009; Singh Panesar \& Markeset, 2008; Tuli, Kohli, \& Bharadwaj, 2007) and also that the service innovation process is more ad-hoc and not as structured as product innovation (Gremyr, Witell, Löfberg, Edvardsson, \& Fundin, 2014). An increased attention to service and support of customer processes (Gebauer et al., 2011; Matheiu, 2001) emphasizes manufacturing firms' service innovation deployment. Deployment refers to the integration of resources into the customer's environment (Tuli et al., 2007). This includes understanding of the customer's environment and the capabilities of customer employees in order to integrate the right set of for 
example information and training. While most service innovation literature has seen service innovation as an output in terms of new value propositions (see, for example, de Brentani, 2001), this research instead argues that it is best understood as a process where both customer and provider collaborate by integrating resources to seek value creation.

One example comes from Finland-based Wärtsilä, a global provider of engines and power solutions for the marine industry. Traditionally, Wärtsilä has competed with technological market leadership; however, since the late 1990s, Wärtsilä has become a provider of complete lifecycle power solutions supporting the customer with usability and also reducing the customer's risk. Wärtsilä develops services that are directed at optimizing performance in fuel efficiency, environmental aspects and operation reliability. Hence, Wärtsilä has changed from a manufacturing firm that develops new technology, to a service-based firm that increasingly supports the customer through the lifecycle of the engine with related services (Salonen, 2011). While several service innovation frameworks are still mainly focused on traditional technology development, there are important exceptions; for example, Nuutinen and Ojasalo (2014) noted that manufacturing firms' increased interest in the customer's process is a source of opportunities where service innovation might emerge.

Hence, the shift towards service implies a closer collaboration and relation between firms, customers, and other service innovation actors (Davies, 2004; Gremyr, Löfberg, \& Witell, 2010; Fang, 2008; Nuutinen \& Ojasalo, 2014; Skålén, Gummerus, von Koskull, \& Magnusson, 2014). This shift also implies that service innovation activities are not limited to the firm; customers and other relevant actors are engaged through active participation (Vargo, Wieland, \& Akaka, 2015). Recently, scholars have argued that value co-creation through interaction between provider and customer is a key service innovation activity (Edvardsson \& Tronvoll, 2013; Lindgreen, Antioco, Palmer, \& van Heesch, 2009). By increasing collaboration, the firm potentially becomes a value co-creator that directly supports the customer's creation of value-in-use during service innovation (Edvardsson \& Tronvoll, 2013). However, supporting customers requires relevant knowledge and an ability to integrate resources.

This thesis follows Mele et al.'s 2014 characterization of service innovation as a process wherein providers and users seek ways to successfully collaborate in resource integration and the fostering of value creation. Service innovation is not seen as a development process outcome (i.e., new technology or new product), but rather as a process that continues through the customers' creation of value-in-use, and where the firm supports customers in their practices (this can be performed both with new or existing resources).

\subsection{Challenges for manufacturing firms}

Despite services' promise, there are both theoretical and empirical problems that arise when manufacturers try to sustain service innovation. Even if innovation and its effect on economy is well established it is less known how service innovation should be understood for manufacturing firms, and how these firms can capture value from it (Fang et al., 2008; Gremyr et al., 2010). Even manufacturers that invest great efforts in developing serivces have difficulty achieving the expected revenues (Gebauer et al., 2005; Neely, 2008). 
Given that manufacturing firms traditionally are concentrated around a core product, only a small part of their total research and development spending is dedicated to new services (Dörner, Gassmann, \& Gebauer, 2011). As a consequence, manufacturer find it difficult and complex to undertake service innovation as it differs from the traditional product innovation process with, for example, more customer cooperation (Santamaria, Nieto, \& Miles, 2012) and more focus on actual delivery (Kindström \& Kowalkowski, 2009).

Further, since the new service-based approach of many manufacturing firms typically include more support of the customer's operations (for example process support), integration of resources in the customer's business is essential in service innovation. However, for manufacturing firms following traditional innovation patterns with a focus on developing new offering, implementation and integration of resources in the customer's process can result in resource bottlenecks (Gebauer et al., 2005). Hence, manufacturing firms need to develop practices in how to integrate and manage resources in the customer's business.

For manufacturing firms, a shift towards service provision also implies organizational changes with dedicated service development functions, market-oriented development processes, and a greater emphasis on customer relationships (Kindström \& Kowalkowski, 2009). Storbacka (2011) argued that manufacturers that integrate product and services into offerings can be challenged by requirements for more internal collaboration (between for example R\&D, marketing, sales and operation) and more customer collaborations. If these aspects are not attended to, there is a risk that the service initiative will fail (Gebauer et al., 2005). For example the Swedish truck manufacturer Volvo increasingly offers services to their products, which is a challenge for employees that are rooted in the traditional "inside-out" perspective and, hence, give less attention to innovations that are not in line with development of new products (Gremyr et al., 2010).

In comparison to traditional innovation, service innovation typically requires extending human capital and cooperation with customers, and a lack of trained employees can be an obstacle for service innovation in manufacturing firms. Cooperation with customers is also essential as services typically are reciprocal processes such as, for example, customer training, technical consulting and technical support. However, manufacturing firms typically do not consider human capital and customer cooperation enough (Santamaria et al., 2012). Also, when acknowledging collaboration, previous research has mainly concentrated on how firms involve customers in the development of new services and customer involvement in service innovation (Bettencourt et al., 2012; Edvardsson, Gustafsson, Kristensson, Magnusson, \& Matthing, 2006; Matthing, Sanden, \& Edvardsson, 2004), for example by involving customers as idea generators or testers (Magnusson, 2003) and hence using them as information resources (Fang, 2008).

\subsection{Exploring realization part in service innovation}

Service innovation in manufacturing firms is despite its inherent promises difficult for many manufacturers to undertake based on several reasons discussed above. Service innovation suffers from vague definitions that not always reflect all the relevant aspects of service innovation for manufacturer. Meanwhile, the demarcation line between manufacturing and service is fading (as 
illustrated in Kone, Wärtsilä and Ericsson cases); therefore, a service innovation framework that acknowledges and supports the dilemmas of manufacturing firms would be beneficial for manufacturer that increase their service business.

In an illustrative example of a manufacturer adopting service innovation, Rubalcaba et al. (2012) showed how Switzerland-based Bossard, a distributor of fasteners in business to business markets, works with service innovation related to the customer instead of an approach limited to the offering (for example, improved delivery time). Bossard instead support customer to design, produce and improve operations in the customer's process in order to achieve better value-in-use for customer. This example shows how a manufacturing firm change its service innovation approach to be directed to the customer and how the firm can supports its customer, instead of looking inwards against the internal processes. Shifting from technology-driven product innovation to value-driven service innovation implies an increased focus on the customer and usage (Bettencourt et al., 2012), as exemplified in the Bossard-example. Hence, this approach to service innovation considers a focus on value creation for customer rather than new service offerings and is hence corresponding with service logic approach. This is a framework that emphasizes the realization as a part of service innovation, that is, activities that do not solely focus on value proposition development but also on what value-in-use can be gained from them through the integration of resources from different actors into the customer's process of value creation. However, traditional internal looking service innovation frameworks (for example, Singh Panersar \& Markeset, 2008), tend not to include the firm's direct interaction with the customer and the potential role as value co-creator, hence realization part of service innovation also need to be included in the extended concept of service innovation.

In contrast to firm-centric approaches that consider the firm as the creator of value, Grönroos (2011) suggests a new focus in marketing were he emphasizes the customer as the creator of value and the surrounding network as a contributor to the process with resources and knowledge. However, value is not delivered with the products and services, but instead is created through the integration of different actors' resources. This approach extends the focus of service innovation from product attributes and offerings per se, to what benefit the services actually render (Heinonen et al., 2010; Michel, Brown, \& Gallan, 2008b; Ordanini \& Parasuraman, 2011). Michel et al. (2008b) support a service logic view on service innovation and argue that traditional innovation research tends to overemphasize product and service attributes (the proposal) instead of seeing differentiated customer use that arises through different contexts and use of resources. Hence, advocating a shift from goods logic (focus on technology and firm as creator of value) to service logic (focus on the process of supporting customers and customer as creator of value (See for example Grönroos, 2011)) in service innovation.

Skålén et al. (2014) argued that service innovation can consist of a combination of new or existing resources and/or practices and offered an example where the customer had difficulties gaining value-in-use from a newly firm-developed operating efficiency value proposition. Due to the customer's low operator competence, the value proposition failed; consequently, the firm had to to come up with several solutions, such as problem-based training for the customer's staff. This 
example shows that service innovation can benefit from including both development activities that are performed before an offering launch, but also deployment activities that represent the practical execution or application of the value proposition and adjustments that need to be done in accordance to the context.

A service innovation process that also considers realization (the actual integration of resources in the customer's process) requires a well-structured use of resources that, for example, covers the balance between efficiency and effectiveness (Grönroos \& Ojasalo, 2004). Working closely with customer potentially increases effectiveness; additionally, optimizing customer input use potentially increases efficiency (Kuusisto, Kuusisto, \& Yli-Viitala, 2013). With increased complexity of service delivery, mechanisms that enable efficiency for the firm and simplicity for the customer are needed in the service innovation process (Kuusisto et al., 2013; Tuunanen \& Cassab, 2011). Balancing efficiency with effectiveness can be achieved by, for example, standardizing back office processes, but keeping front office customization (Ulaga \& Reinartz, 2011). However, recent research reports that too extensive focus on efficiency and cost reduction can reduce revenue (Rust \& Huang, 2009). Therefore, efficient realization methods that preserve service quality while simultaneously using resources efficient become critical.

Realization differs from, for example, diffusion, implementation, and commercialization that address the task of striving for commercial success of a new offering (Garcia \& Calantone, 2002; Singh Panesar \& Markeset, 2008) by implying that innovations can occur jointly with customers (Skålén et al., 2014). Realization in this thesis is seen as a part of service innovation where firm and customer resources are integrated into the customer's creation of value-in-use in relation to new or existing value propositions. In this sense, the service innovation approach invokes service logic scholars that suggest value is created by customers as value-in-use (Grönroos \& Ravald, 2011).

\subsection{Research purpose and research questions}

Increasingly, calls for gaining understanding of the process of service innovation is heard from leading scholars (Edvardsson \& Tronvoll, 2013). The discussion of the nature of service innovation is only in its beginning (Carlborg, Kindström, \& Kowalkowski, 2014), and during the last decades, different aspects of service innovation have been intensively discussed in academia, (i.e., developing offerings, involving customers, profiting from service innovation). However, today not only the offering per se is in focus, but, increasingly the customer's usage and the creation of value-in-use is also attracting attention, particularly in manufacturing firms that move towards service.

Even if service innovation has described implementation as a part of the service innovation process (Singh Panesar \& Markeset, 2008) research on service innovation tends to be internal looking, primarily directed at the process of developing new value propositions, and hence less research has focused on how service innovation contributes to value-in-use (Rubalcaba et al., 2012; Song, Song, \& Di Benedetto, 2009).

Even innovation processes that are recognized with both a technological and a market aspect (i.e., commercialization) still are often technology-focused (Kjellberg, Azimont, \& Reid, 2015). As a result, even if firms develop promising new technology and new concepts, they fail to recognize how this 
will benefit the customer (Mele, Colurcio, \& Russo-Spena, 2014). In contrast to the traditional focus on the outcome of service innovation in terms of new value propositions (Song et al., 2009), leading scholars call for service innovation research with a process approach to service innovation that instead see improved customer value creation as outcome of the process (Edvardsson \& Tronvoll, 2013). However, only recently have a few researchers actually discussed a service logic or S-D logic approach to service innovation as an potential avenue (Edvardsson \& Tronvoll, 2013; Nuutinen \& Ojasalo, 2014; Rubalcaba et al., 2012) and also the integration of the traditional approach (development of offering per se) and the realization approach (Lusch \& Nambisan, 2015; Siltaloppi \& Toivonen, 2015). Acknowledging realization as an important phase in service innovation, the overall purpose with this thesis is: to describe and analyze realization as part of service innovation in manufacturing firms.

The purpose is deconstructed into the following research questions:

- What are the main characteristics of the realization part of service innovation?

This research question will explore what characteristics that reflect the realization part of service innovation. Previous literature that address service innovation in manufacturing firms has been vague in describing what an increased interest in customer's processes implies for the service innovation process (Santamaria et al., 2012). Hence, a deeper understanding of realization in the service innovation process and its characteristics in a manufacturing context is relevant.

- How do firm and customer interact in service innovation realization?

Edvardsson and Tronvoll (2013) argue that a key to understand service innovation is to understand co-creation and hence the interaction between the involved actors. However, literature on service innovation, also literature with a service logic or S-D logic approach, provides scarce understanding for how interaction takes place in service innovation. As with the development of the serivtized economy where manufacturers infuse service to already existing products, individual firms can have difficulty procuring all needed resources without the support from other actors, hence resources and competence need to be found in the surrounding network (Rusanen et al., 2014). Maglio et al. (2009) argue that in order to understand service innovation, new service innovation mindsets are needed. Previous service innovation literature tends to be dominated by tangible goods-dominant (G-D) logic (Perks, Gruber, \& Edvardsson, 2012), thus emphasizing the need for research that explores possible resource contributions from both the firm and customer and the linked interactions in the service innovation process.

- How can service productivity be understood vis-à-vis realization?

The third research question addresses the challenges of service productivity that arises when including realization in service innovation, as the balance between satisfying heterogeneous customer need in accordance to efficiency becomes important. Previous literature has argued for standardizing back-office processes while customizing front-office processes (Ulaga \& Reinartz, 2011). However, how to manage this efficiency dilemma when considering both firm and customer resources in the service innovation process has received less attention. Therefore, research that 
address service productivity challenges in service innovation processes that span realization is needed.

The purpose and the research questions will together shed light on realization part of service innovation (how it can be characterized, how firm and customer interact and how it can be efficient with regard to both firm and customer) and, hence, contribute to service innovation research in manufacturing. How actors contribute with resources in different degrees, which is the focus of research question two, has typically been related to the customers' contribution with resources into the firm's development process; however, a service logic perspective also considers the firm's involvement in the customer's value-creating process.

In order to study service innovation, the study has followed manufacturing firms that increasingly integrates services into their core offerings and supports their customers' processes as an important part of the process.

\subsection{Contributions of papers and their linkage to the research purpose}

Considering the contributions from the papers to the overall purpose and the research questions, Table 1 illustrates the contributions of the papers. Paper I is a literature review that explores the development of service innovation in a broad context. Paper II is a conceptual study exploring a lean approach in service and how it can be used for a more efficient service approach. Paper III is a multiple case study that explores service modularization and modular strategies. Paper IV is a case study that analyzes network aspects of new service development by using data from three different actors in a triad. Paper $\mathrm{V}$ is an empirical case study that elaborates on customer involvement in service processes. See also chapter four for brief summaries of the five appended papers. See Table 1 for the appended papers linkage to the research questions. 
TABLE 1 APPENDED PAPERS AND THEIR LINKAGE TO THE RESEARCH QUESTIONS

\begin{tabular}{|c|c|c|c|c|}
\hline Paper & Focus & Paper type & Main contribution & Linkage to RQ \\
\hline Paper I & $\begin{array}{l}\text { Service innovation in } \\
\text { general }\end{array}$ & $\begin{array}{l}\text { Literature review } \\
\text { and conceptual }\end{array}$ & $\begin{array}{l}\text { Understanding and } \\
\text { synthesis of the } \\
\text { service innovation } \\
\text { concept and its } \\
\text { evolution }\end{array}$ & RQ 1 \\
\hline Paper II & Service productivity & Conceptual & $\begin{array}{l}\text { Exploring a lean } \\
\text { approach for service } \\
\text { and its relevance for } \\
\text { developing new } \\
\text { services }\end{array}$ & RQ 3 \\
\hline Paper III & $\begin{array}{l}\text { Service modularity } \\
\text { and co-creation }\end{array}$ & Case study & $\begin{array}{l}\text { Exploring the } \\
\text { concept of } \\
\text { modularity and its } \\
\text { link to realization and } \\
\text { productivity }\end{array}$ & RQ 3 \\
\hline Paper IV & $\begin{array}{l}\text { Triadic value } \\
\text { proposition and } \\
\text { service network }\end{array}$ & Case study & $\begin{array}{l}\text { Explores network } \\
\text { aspects of new } \\
\text { service development } \\
\text { by investigating a } \\
\text { whole triad }\end{array}$ & RQ 2 \\
\hline Paper V & $\begin{array}{l}\text { Interaction and co- } \\
\text { creation in service } \\
\text { innovation }\end{array}$ & Case study & $\begin{array}{l}\text { Elaborates on } \\
\text { customer } \\
\text { contributions in the } \\
\text { service innovation } \\
\text { processes }\end{array}$ & RQ $1 \& 2$ \\
\hline
\end{tabular}

\subsection{Disposition of the thesis}

The rest of the thesis is as follows: first, relevant references will provide a background to extant research in the field. This chapter is followed by a description of how the thesis was conducted in relation to relevant methodological considerations. Before moving on to discussion and research findings, the five appended papers are briefly introduced. The thesis ends with the conclusions and some comments on managerial implications and possible future research. 


\section{FRAME OF REFERENCES}

The next section presents the background and most influential theoretical tracks and perspectives of this thesis. This chapter first discusses service innovation and its origins to map the literature against traditional (product) innovation. Subsequent sections summarize the partly parallel rise of a new perspective on service - service logic - that emphasizes value creation, resources, and networks. Service innovation and service logic literature is partly intertwined and sometimes overlaps, but since this thesis focuses on service innovation, especially vis-à-vis realization, service logic serves as a perspective.

\subsection{A background to service innovation literature}

Service innovation as its own subject gained momentum during the late 1980s and 1990s (Paper 1, Carlborg et al., 2014). The initial technologist (assimilation) approach used models and theories from both the manufacturing and service sectors. For example, innovation was referred to as, "a new technology or combination of technologies introduced commercially to meet a user or a market need" (Utterback \& Abernathy, 1975, p. 642). This approach studied technology as a part of service innovation; for example, by the use of information and communication technology (Gallouj, 1998; Gallouj \& Savona, 2009). Later, the demarcation approach, which argued that service innovation is different from product innovation, and hence in need of own models and theories, gained favor 
(Edvardsson \& Olsson, 1996; Gallouj \& Weinstein, 1997; Sundbo, 1997). With empirical support from the Swedish telecom industry, Edvardsson and Olsson (1996) emphasized providers' offering customer value-creation opportunities and not the services per se. Sundbo (1997) investigated 21 financial industry, tourism, and management consultancy firms and found that innovation, though also relevant, can be difficult to separate from organizational learning. These early studies were linked by the notion that innovation cannot be limited to new technology and products.

The discussion of service versus product innovation follows an intense debate over the myopic approach to marketing that ignored services' inherent potential (Fisk, Brown, \& Bitner, 1993; Shostack, 1977). Services are basically processes; hence, the division between product and process is problematic (Gallouj \& Weinstein, 1997). Both the technologist and demarcation approaches are subject to bias, with the former being too broad and the latter too focused (technologist approach tend to underestimate and undermine the specifies of services while demarcation approach instead overly focused sectorial and case specific typologies) (Gallouj \& Djellal, 2011). To bridge these two approaches, Gallouj and Djellal (2011) argued for a synthetic or integrative framework that is compatible with innovation in manufacturing. See Table 2.

TABLE 2 PERSPECTIVES ON SERVICE INNOVATION

\begin{tabular}{|c|c|c|c|}
\hline & $\begin{array}{l}\text { Assimilation } \\
\text { (technologist) }\end{array}$ & Demarcation & Synthesis (integrative) \\
\hline $\begin{array}{l}\text { How service } \\
\text { innovation is } \\
\text { viewed }\end{array}$ & $\begin{array}{l}\text { - A special case of } \\
\text { product } \\
\text { innovation }\end{array}$ & $\begin{array}{l}\text { - Fundamentally different } \\
\text { from product innovation (for } \\
\text { example service uniqueness } \\
\text { through IHIP; intangibility, } \\
\text { heterogeneity, inseparability, } \\
\text { \& perishability) }\end{array}$ & $\begin{array}{l}\text { - Service innovation directed } \\
\text { at improving customer value }\end{array}$ \\
\hline $\begin{array}{l}\text { Customer } \\
\text { role }\end{array}$ & $\begin{array}{l}\text { - Passive reciever, } \\
\text { buyer }\end{array}$ & $\begin{array}{l}\text { - Customer as source of } \\
\text { information and discusison } \\
\text { partner }\end{array}$ & $\begin{array}{l}\text { - Customer as the creator of } \\
\text { value }\end{array}$ \\
\hline Provider role & - Innovator & $\begin{array}{l}\text { - Innovator together with } \\
\text { customer }\end{array}$ & $\begin{array}{l}\text { - Co-creator together with } \\
\text { customer }\end{array}$ \\
\hline $\begin{array}{l}\text { Types of } \\
\text { service } \\
\text { innovation }\end{array}$ & $\begin{array}{l}\text { - Improvements in } \\
\text { the firm's internal } \\
\text { processes (e.g., } \\
\text { reducing cost in } \\
\text { production } \\
\text { process) }\end{array}$ & $\begin{array}{l}\text { - New service concept (e.g., an } \\
\text { online tool) } \\
\text {-New service delivery system } \\
\text { (e.g., a new channel) }\end{array}$ & $\begin{array}{l}\text { - Optimization of customer } \\
\text { use through new value } \\
\text { propositons or through } \\
\text { improved customer processes } \\
\text { (e.g., process optimization in } \\
\text { customer process) }\end{array}$ \\
\hline $\begin{array}{l}\text { Important } \\
\text { service } \\
\text { dimensions }\end{array}$ & $\begin{array}{l}\text { - Internal } \\
\text { production } \\
\text { processes } \\
\text { - Internal } \\
\text { efficiency }\end{array}$ & $\begin{array}{l}\text { - New resources } \\
\text { - Understandning customer } \\
\text { needs }\end{array}$ & $\begin{array}{l}\text { - New customer interaction } \\
\text { - New value systems (set of } \\
\text { actors) } \\
\text { - Customer experiencies and } \\
\text { context }\end{array}$ \\
\hline
\end{tabular}




\subsection{Synthesis approach to service innovation}

Blurring sector boundaries partly arises when manufacturing firms increasingly offer services (Gebauer, Gustafsson, \& Witell, 2011). Developing value propositions that include both services and products provides an innovation framework that supports all these activities across sectors. A broader approach to service innovation is sometimes called an integrative synthesis since it tries to merge scholars from both products and services (Gallouj \& Savona, 2009), as well as the technologist approach and the demarcation approach (Gallouj, 1998).

One of the first synthesis approaches that did not made a clear distinction between service and manufacturing, and that formed an early service innovation model appeared in Gallouj and Weinstein's 1997 study. The model considered both technological and non-technological innovation, and represented services and goods as four vectors of characteristics and competencies: outcome characteristics, provider competencies, provider technological characteristics, and customer competencies. Developing these vectors led to six modes of innovation: radical, improvement, incremental, ad hoc, recombinative and formalization (see Table 3). This framework breaks with the previous distinction between process and product innovation (See, for example, Utterback \& Abernathy, 1975) as it focuses more on the characteristics and content of innovation rather than the outcome. Further, it extends the focus to either radical or incremental innovation. See. Table 3

TABLE 3 INNOVATION TYPES ACCORDING TO GALLOUJ \& WEINSTEIN (1997)

\begin{tabular}{|l|l|}
\hline Innovation type & Example \\
\hline Radical & The identification of and entering into a new area of expertise \\
\hline Improvement & $\begin{array}{l}\text { Improving certain characteristics without any change of the } \\
\text { structure of the system }\end{array}$ \\
\hline Incremental & $\begin{array}{l}\text { Reduction in production costs by adding or changing certain } \\
\text { technical characteristics }\end{array}$ \\
\hline Ad-hoc & $\begin{array}{l}\text { Innovation produced jointly by service providers and customers } \\
\text { during the process of delivery. }\end{array}$ \\
\hline Recombinative & Creation of a totally new service by combining existing elements \\
\hline Formalization & Putting service characteristics into order, for example modulization \\
\hline
\end{tabular}

Among the authors responding to Gallouj \& Weinstein (1997), de Vries (2006) suggested that customers' technological competencies should be included. In this manner, de Vries (2006) emphasized interaction between providers and customers in service innovation, as well as different actors in the network. By emphasizing the active and co-producing role of the customer, this innovation framework is interactive and non-linear. The 2010 study by den Hertog et al. also emphasized network capabilities in service innovation. However, den Hertog et al. lacked empirical examples for their model. Even if firm-driven interaction with other stakeholders typically has concerned how to involve customers as idea generators or information resources (see, for example, Alam, 2002), it has gained a great deal of criticism since it reduces the customer to a passive receiver 
of value embedded in products, rather than a definer of value within a context and a specific use situation (Ng \& Smith, 2012; Ravald \& Grönroos, 1996; Vargo \& Lusch, 2004).

Literature that emphasizes external resources has increasingly noted the reciprocal nature of service innovation involvement and also the network's role (Rusanen et al., 2014; Möller, Rajala, \& Westerlund, 2008). Network theory has long recognized how business relationships are connected; changes in one will always affect others to different degrees (Håkansson \& Ford, 2002). Service networks sometimes are characterized as a, "loosely coupled collection of upstream suppliers, downstream channels to market and ancillary service providers" (Gebauer, Paiola, \& Saccani, 2013; p. 32). Such networks must consider more than the dyadic customer-provider relationship since more actors are affected, thus leading to a focus on triads and more extensive networks.

Further emphasizing the customer, Michel et al. (2008b) argued that service innovation is not defined by what it can offer, but rather what the customer can do with it and the value thus created; the approach to innovation, therefore, should change from products and services to resource integration and enhanced value propositions. This implies a shift from exchanging the outcome from an innovation to seeing service innovation as fulfilling a value-development process by applying resources in different forms (knowledge and skills) from both customers and the firm. Michel et al. used empirical examples from different product-based industries that showed how the firms, through innovative offerings, changed both the customer's role and the firm's value creation. The customer can consist of a user, buyer and/or payer; hence, the role can be changed in different dimensions. Thus, Michel et al. provided an interesting example of how innovation can be illustrated with a service logic, emphasizing that innovation builds upon a significant change in how customers co-create value (for example, Sweden-based furniture manufacturer IKEA changed the customer's role since they provide self-selection and self-assembling of furniture).

\subsection{Involving customers in service innovation}

As service innovation became broader and more established, several scholars argued that customer involvement reduces cycle times (Alam, 2002) and increases profitability (Matthing et al., 2004; Witell, Kristensson, Gustafsson, \& Löfgren, 2011). For the best outcomes, such as speed to market and economic return, scholars have suggested varying customer involvement intensity at different service innovation stages (Alam, 2002; Alam \& Perry, 2002; Edvardsson, 1997; Edvardsson et al., 2012; Jong \& Vermeulen, 2003; Kindström \& Kowalkowski, 2009; Scheuing \& Johnson, 1989). For example, more intense customer involvement early in the process is often most beneficial (Alam \& Perry, 2002). Also, involvement intensity can vary depending on business type and complexity level (Edvardsson et al., 2006). Kindström and Kowalkowski's 2009 study of 10 manufacturing firms that offer services to their customers identified how manufacturers familiar with product innovation must consider significant customer involvement not just in development of offerings, but also in cocreating resource integration.

Service innovation processes can consist of both physical and mental contributions and different researchers use different terms to describe customer contributions; for example, customer involvement, customer participation, customer integration, and co-creation (Fliess, Dyck, \& 
Schmelter, 2014). Customer involvement has been discussed extensively in the fields of service marketing and management, especially vis-à-vis new service development and service innovation (Alam, 2002; Alam, 2011; Kristensson, Matthing, \& Johansson, 2008; Lundkvist \& Yakhlef, 2004; Magnusson, Matthing, \& Kristensson, 2003). The literature typically has considered the customer as an information resource or source of ideas that can be used when developing value propositions. According to Alam (2006) and Matthing et al. (2004), involvement refers to the level of interaction between the service firm and one or more customer representatives at different development phases. Dadfar et al. (2013) also emphasized that customer involvement is linked to the degree of participation.

Several other benefits of involving customers have been suggested. Witell et al.'s 2011 study addressed manufacturers from different industries (wood, pulp and paper, machinery and equipment, and construction, etc.) and argued that customer co-creation is present during the entire service innovation process where the customer can act both as a idea creator (co-creation for others) and creator of value-in-use (co-creation for use).

\subsection{Value propositions - a promise of what?}

Looking at the extant literature, value proposition research is widespread and different scholars give the concept different meaning. Frow et al. (2014) identified six different value proposition metaphors: a promise, a proposal, an invitation to play, a bridge connecting our worlds, a wild card, a journey to a destination. Ballantyne and Varey (2006) suggested that value propositions are proposals with reciprocity expectations. Also, Grönroos and Voima (2013, p. 146) argued that, "value proposition must be considered a promise that customers can extract some value from an offering". Maglio et al. (2009) argued in greater detail that three value co-creation activities are key: interaction through a proposal to another actor (or system), followed by agreement and realization of proposal activities. Hence, value proposition plays an important role in service innovation as the proposal of future value through interaction.

Close to the term "value proposition" is the concept of "service offering", or only offering. Kowalkowski, Kindström \& Brehmer (2011) identified several manufacturing industry service offerings in their case study of two firms: operations training, process optimization, service-level agreements and more. According to the authors, there are several challenges for manufacturers that offer service offerings; for example, exploration needs to be balanced with exploitation in order to reduce costs. Further, the internal cooperation between product and service organizations is critical to master industrial service offerings.

Service innovation and value propositions are interconnected through development, but also via customer co-creation (Skålén et al., 2014). First, propositions are often seen as a first stage towards value creation; resources that are integrated depending on customer acceptance of the value proposition are used to connect the firm with other actors (for example, suppliers, intermediaries, customers) (Lusch et al., 2010).

Second, according to service logic, the provider has the opportunity to be directly involved with the customer (Grönroos, 2011; Grönroos \& Voima, 2013). Value-extraction potential lies in the 
customer's ability and competence of integrating firm-provided resources. Skålén et al. asked: "How does the firm make sure that the value proposition can be used so that value-in-use emerges for the customer, according to the firm's promise?" (2014, p. 8). Examples can be helping the customer reduce energy costs in a pulp industry, instructing the customer how the welding process is managed, and optimizing the customer's route planning so they can help their customers faster. (Skålén et al., 2014).

It is worth noting that a value proposition does not contain value per se, but only potential value that can be created by the customer, or by support from the firm that, in these cases, acts as a co-creator. Therefore, the value proposition is valuable as it gives the customer an indication of what to expect for value-in-use related to the innovation.

\subsection{Realization as a an integral part of service innovation}

Rather than being limited to developing value propositions, service innovation concerns improvements in the entire customer value creation chain according to service (and servicedominant) logic (Ordanini \& Parasuraman, 2011; Rubalcaba et al., 2012). According to Edvardsson \& Tronvoll (2013), value co-creation is a key to understand service innovation; that is, how the involved actors are structured and how they integrate resources. For example, according to Tuli et al. (2007), "deployment of services" refers to the actual integration into the customer's environment and includes providing appropriate information and training.

Research suggests that service innovation also includes practices (Bledow, et al., 2009; Skålén et al., 2014). Integrating value proposition development and realization shapes the innovation process, and avoids a narrow focus on each part (Siltaloppi \& Toivonen, 2015). Lusch \& Nambisan (2015) argued that the value proposition is a platform for further value co-creation and hence service innovation needs to consider both aspects of developing value propositions and the interlinked value cocreation. Realization emphasizes ongoing service practices, co-creation, integration of resources from diverse actors and further interlinked service development (Lusch \& Nambisan, 2015; Siltaloppi \& Toivonen, 2015; Toivonen \& Tuominen, 2009). This conceptualization also goes back to Gallouj \& Weinstein (1997) and their ideas of ad hoc innovations that emerge during interactions between firm and customer. However, prior research on service innovation, rooted in technological innovation, has had a clear focus on the activities before launch and the related diffusion. For example, Hauser, Tellis, \& Griffin (2006, p.687) argue that innovation is "the process of bringing new products and services to market".

An interesting model was presented by Storbacka (2011) who discussed the development of new solutions (combinations of products and services that address individual customer need, often strategically important, according to Storbacka (2011)) in a wide range of product-based industries, including mining and construction, forklift trucks, electronic manufacturing services, industrial machinery, shipbuilding, etc. All the product-based firms were interested in developing services in addition to their product portfolios. Storbacka identified the existence of two parallel new-solution development processes: commercialization and then industrialization. Rather than combinations of goods and services, Storbacka viewed commercialization as being directed towards improving 
customer knowledge of value-creating processes, and industrialization as being more focused on generating innovations and defining their management. Storbacka argued that developing a solution and the framework for its implementation needs both customer insights and firm resources, and should consider commercialization and industrialization. Storbacka also noted that solution delivery can last for a long time in "post-deployment" phases that need long-term commitment from both firm and customer. Storbacka's research is interesting as it concentrates on product-based firms, applies a service logic where solutions are seen as relational rather than combinations of various goods and services elements, and acknowledges the long-term delivery perspective through reciprocal engagement.

Siltaloppi and Toivonen's 2015 study of five empirical cases in the Finnish residential sector identified four aspects of development (planning) and realization (execution), of which three are relevant to this thesis: organization, interaction focus and process logic. While the development phase is primarily top-down, realization is typically bottom-up, meaning that the innovation process requires a balance between formal structure and employee initiative (Fuglsang \& Sundbo, 2005; Sundbo \& Gallouj, 2000). Traditionally, service delivery involves frontline employees who facilitate postpurchase process activities (Moorman \& Rust, 1999). In addition, innovation research argues that creativity is required during realization since unforeseen challenges arise (Mumford, Scott, Gaddis, \& Strange, 2002). Therefore, creative ideas stemming from employees are an important part in the realization phase (Mumford et al., 2002).

While customer involvement in service innovation has typically focused on information from a firmperspective, emerging literature (with service or S-D logic) increasingly emphasizes the customers' and other stakeholders' active contribution to the service innovation process (Ordanini \& Parasuraman, 2011). Offering development is traditionally represented as an internal, productcentric, linear and sequential process with predefined steps that separates innovators from adopters (Alam \& Perry, 2002; Scheuing \& Johnson, 1989; Vargo et al., 2015), while the realization phase emerges more from customer needs and emphasizes collaboration (Ordanini \& Parasuraman, 2011). See Table 4.

TABLE 4 DEVELOPMENT AND REALIZATION PART OF SERVICE INNOVATION, ADOPTED FROM SILTALOPPI \& TOIVONEN (2015)

\begin{tabular}{|l|l|l|}
\hline & \multicolumn{2}{|c|}{ Service innovation process } \\
\hline & \multicolumn{1}{|c|}{ Development } & \multicolumn{1}{c|}{ Realization } \\
\hline Organization & Top-down & Bottom-up \\
\hline Interaction & $\begin{array}{l}\text { Involving the customer in the } \\
\text { provider's development process }\end{array}$ & $\begin{array}{l}\text { Firm is involved in the customer's } \\
\text { processes }\end{array}$ \\
\hline Process & Internal, linear and sequential & Emerging from customer need \\
\hline
\end{tabular}


Kindström \& Kowalkowski (2009) identified four important service innovation stages. In their framework, market sensing and development are part of planning service innovation, while sales and delivery go beyond the traditional scope of developing a new service that traditionally ends with the launch of the service offering. The four stages are in line with Mumford et al. (2002). This framework contrasts with traditional service innovation literature (see, for example, Alam \& Perry, 2002 and Scheuing \& Johnson, 1989) by including more frequent interaction with customers in the development stage, and also being more people-intensive in the delivery phase. This is in line with Mumford et al. (2002) which emphasized service development's iterative nature and the importance of using skilled employees that can respond to new challenges. Of particular note is the presentation of a framework that is directed to manufacturing companies. Hence the framework from Kindström \& Kowalkowski (2009) is an attempt to bridge the different aspect of development and realization in manufacturing firms (in terms of organization, process, and interaction) since it covers both phases.

To address firm involvement in the customer's process and the fulfilment of the proposed value, this thesis uses the term "realization", as it gives an indication that something is taken into practical use; it also shows similarities to the terminology by Maglio et al. (2009) for activities in service interaction. However, service innovation differs from interaction and service in its indication of novel or new resources or activities that are in focus. While "service" is characterized as, "support for an individual's or organization's everyday processes in a way that facilitates (or contributes to) this individual's or organization's value creation" (Grönroos \& Gummerus, 2014, p. 208), "service innovation" is understood as a process wherein provider and user together seek novel ways that enable them to successfully collaborate in resource integration and value creation. The service process is hence more of a routine while service innovation is connected with some aspect of novelty (on the resources deployed or activities). However, both service and service innovation strive to improve value-in-use. This view also allows for smaller improvements to be included in service innovation depending on the context (for example, for a conservative customer, a new practice can be seen as an innovation, while for a customer with more developed processes, it is seen as a minor incremental improvement).

To summarize the discussion on realization, there is an emerging stream of research that conceptually expands service innovation to include both the development and realization of the value propositions with a focus on value-in-use, interaction and co-creation (Edvardsson \& Tronvoll, 2013; Skålén et al., 2014). There are several reasons for this: first, scholars argue that service innovation is not only a matter of what a value proposition is promising but also how it is implemented. Second, even if the conceptual ideas of innovation in the realization phase were mentioned already by Gallouj and Weinstein (1997), much of service innovation still focuses on the development phase and the outcome in terms of new value propositions instead of actual value for the customer, which results in a myopic service innovation concept (Möller et al., 2008). 


\subsection{Service productivity and innovation}

Gallouj \& Weinstein's 1997 study introduced both incremental and improvement innovation modes. The latter implies reduced production costs by improved efficiency. In this sense, it becomes relevant to also include productivity as related to service innovation, especially in the realization phase (See for example Skålén et al., 2014). However, improved productivity in a service context is different from productivity in a traditional goods context since the customer provides significant input to the process (Geum, Shin, \& Park, 2011) and as there is a potential risk of lower customer satisfaction through decreased customer value-in-use (Rust \& Huang, 2012). Therefore, service productivity need a wider perspective, as it depends on efficiency of firm, customer input and on customer satisfaction (Calabrese, 2012; Grönroos \& Ojasalo, 2004). A recent literature review by Maroto-Sanchez (2012) illustrates the emerging view of service productivity as a combination of both efficiency and effectiveness.

Efficiency often relates to service process inputs and outputs, with the former divided into those of the service provider and the customer (Grönroos \& Ojasalo, 2004; Johnston \& Jones, 2004). According to Johnston and Jones (2004), operational productivity includes the service provider's inputs such as personnel, technology, systems, and information as well as the customer's time and effort. To assess the total productivity, effectiveness also must be evaluated because the service process and service product often overlap.

Customer satisfaction (effectiveness). Customer-perceived service quality can be difficult to keep when increasing efficiency (unlike in manufacturing); as a consequence, neither can firm profitability (Djellal \& Gallouj, 2010; Grönroos \& Ojasalo, 2004; Johnston \& Jones, 2004). This is an important service productivity notion. However, most authors do not integrate efficiency and effectiveness, viewing them as separate phenomena. Customer satisfaction adds a new dimension to calculating productivity, compared with the traditional way of doing so in a manufacturing context (Grönroos \& Ojasalo, 2004). Johnston and Jones (2004) labeled effectiveness as customer productivity and showed how it can actually be undermined by increasing efficiency. When an operation was accelerated (increased efficiency), the result was poorer customer perceived value, with the result that service productivity did not increase despite the faster operation time.

According to Grönroos \& Ojasalo (2004), the link between efficiency, customer satisfaction, and productivity can be understood through the progression of the actors' relationship. In parallel processes that emerge through relationship continuity, the firm learns about real customer needs and their associated knowledge and competencies. This gives the firm the opportunity first to better align the services with customer needs, but also to allow the customer to contribute with own resources where possible in accordance with the customer's level of competence. From the customer's standpoint, interacting with the provider offers improved service knowledge, and, hence, a better match between expectation and experience. Also, awareness of the service allows contributing more intensely. In sum, higher productivity can be reached through a better use of both customer and firm resources, but also a higher customer satisfaction through a better match between expectations and experiences. Both these dimensions can contribute to a higher 
productivity. This model by Grönroos \& Ojasalo (2004) contrasts with traditional productivity approaches; see Figure 1.
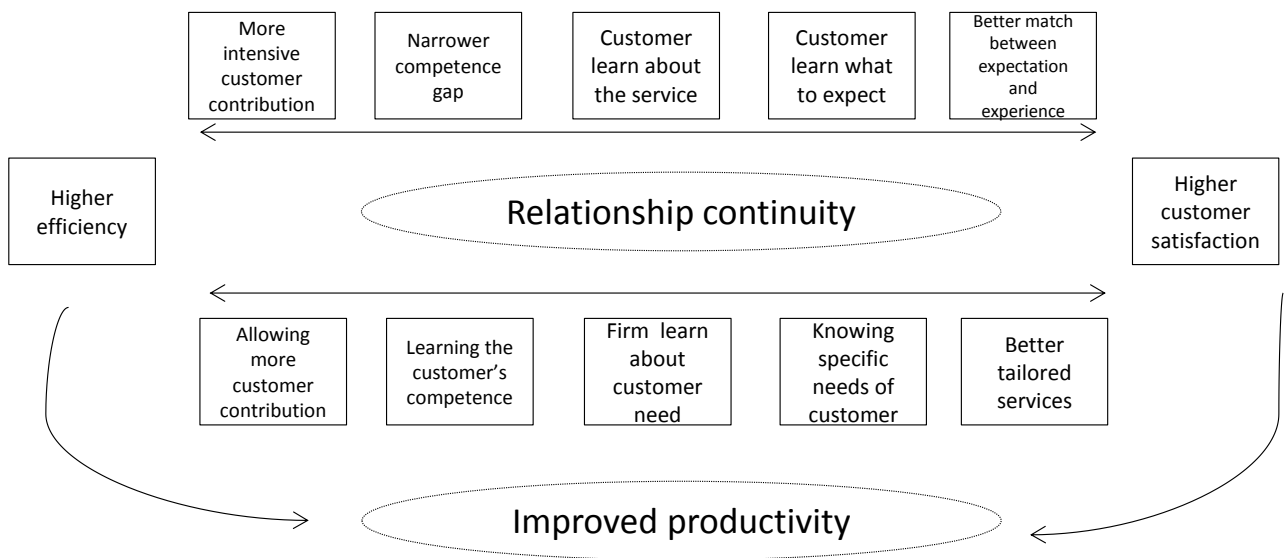

FIGURE 1 SERVICE PRODUCTIVITY MODEL ADOPTED FROM GRÖNROOS AND OJASALO (2004)

Improvements in the customer's process and increased service productivity can be seen as aspects of service innovation that creates value for customers with new routines or standards. Improvements as a part of service innovation was previously acknowledged by Gallouj \& Weinstein (1997); however, with a deeper focus on customer value creation and how changed practices can improve value, it is well-aligned with an extended approach to service innovation (Rubalcaba et al., 2012; Skålén et al., 2014). The notion of customer-firm interactions improving customer satisfaction as well as efficiency (Grönroos \& Ojasalo, 2004) is interesting for service innovation research where interaction between customer and firm, and the use of resources from both actors, become increasingly relevant (Rusanen et al., 2014), especially when applying a service logic approach.

\subsection{Service logic - an interactive approach to service innovation}

The final section in this chapter discusses the emerging service logic perspective vis-à-vis value creation and its relation to service innovation. A study by Edvardsson, Gustafsson, and Roos (2005), identified two approaches within service research: first, the traditional view of service as a market offerings category, and second, service as a perspective on value creation. Traditionally, service is described as market offerings of deeds, processes, and performances in line with the first category (Zeithaml \& Bitner, 2000). The second approach of seeing service as a value creation perspective gained momentum through a seminal 2004 Vargo and Lusch article. Even though many had previously identified the service perspective on value creation (see, for example, Normann \& Ramirez, 1993), Vargo and Lusch made a big impact by approaching service as not limited to only a separate case of a market offering.

Seeing service more as a perspective on value creation provides a platform for further analysis (Edvardsson et al., 2005; Grönroos \& Ravald, 2011). This perspective ("service logic") has important implications for the marketing field itself (Grönroos \& Ravald, 2011); for example, it implies that 
production and value creation are separate, with resources that later can be used for value creation produced by the firm for customers to use (Grönroos, 2008; Grönroos, 2011; Grönroos \& Ravald, 2011). Hence, the scope of service widens as it considers both resource production and the value created (Grönroos \& Voima, 2013).

The service logic approach is customer- rather than firm-centric, and provides a new way of interpreting service innovation (Edvardsson \& Tronvoll, 2013; Ordanini \& Parasuraman, 2011; Rubalcaba et al., 2012). Even though service logic scholars not are presenting a new theory per se, they suggest a new perspective on marketing (Vargo, 2011). As an example, Vargo (2008, p. 214) proposed that, " $a$ [. . . ] firm's activity is best understood in terms of input for the customer's resourceintegration, value-creation activities rather than it is in terms of its own integration of customer resources for the 'production' of valuable output". This contrasts with traditional marketing beliefs that the firm creates and delivers value into the customer's environment. Instead, it is a customercentric approach that takes its starting point from value-in-use, and the provider's co-creator role (Grönroos \& Voima, 2013; Ng \& Smith, 2012). Basically, there is a demarcation between firm-centric approaches that argue value is created by the firm through activities, and customer-centric approaches that argue value is judged and perceived by the customer ( $\mathrm{Ng} \&$ Smith, 2012).

A lot of criticism has been raised against the customer being reduced to a passive receiver of product-embedded value, instead of a creator of value within a context and a specific use situation (Ng \& Smith, 2012; Ravald \& Grönroos, 1996; Vargo \& Lusch, 2004). Emerging approaches, including service-dominant (S-D) logic, or service logic, emphasize the contextual-dependent value that the customer creates (Grönroos, 2008; Vargo \& Lusch, 2004, 2008). Before the moment of use, only potential value exists; instead, the role of suppliers and service providers is to produce resources with which customers create their own value. However, the customer is not always alone in the value-creation processes, which rely on various actors in value constellations (Normann, 2001). See Table 5 for a comparison between firm-centric and customer-centric approaches.

TABLE 5 FIRM-CENTRIC AND SERVICE LOGIC APPROACH TO VALUE CREATION AND INNOVATION

\begin{tabular}{|l|l|l|}
\hline & Traditional firm-centric approach & $\begin{array}{l}\text { Service logic approach (Customer- } \\
\text { centric) }\end{array}$ \\
\hline Description of value creation & $\begin{array}{l}\text { The firm creates and delivers value } \\
\text { in forms of products and services }\end{array}$ & $\begin{array}{l}\text { Value creation is the customer's } \\
\text { creation of value-in-use. Value-in- } \\
\text { use is created during use of } \\
\text { resources. }\end{array}$ \\
\hline $\begin{array}{l}\text { Role of the firm in innovation } \\
\text { process }\end{array}$ & Producer and innovator & $\begin{array}{l}\text { Firm is a facilitator or co-creator of } \\
\text { the experience, contributing with } \\
\text { innovation process }\end{array}$ \\
\hline $\begin{array}{l}\text { Role of the customer in } \\
\text { are passive actors and value is } \\
\text { created when it is delivered. }\end{array}$ & $\begin{array}{l}\text { The customer creates value-in-use } \\
\text { by contributing with resources and } \\
\text { knowledge. The customer is an } \\
\text { active actor. }\end{array}$ \\
\hline
\end{tabular}


Using service logic to understand service innovation emphasizes customer value creation rather than raw output due to services being conceptualized as a, "new and useful process of application of specialized competencies (knowledge and skills through deeds, processes, and the performances for the benefit of another entity or the entity itself)" (Vargo \& Lusch, 2004, p. 2). According to Grönroos (2011), value creation is, "a process through which the user becomes better off in some respect" ( $p$. 282). In line with these thoughts, Möller et al. (2008) argued that it is the benefit that the customer gains from the service innovation, not the offering per se, that is the perceived value for the customer. Hence, a service logic approach to service innovation implies that the firm has an opportunity to directly interact with the customer and co-create value, which implies that the firm is not restricted only to the offering itself, but can also actively influence the fulfilment of customer value (Grönroos \& Gummerus, 2014). Grönroos and Gummerus (2014) call these implications a revolution for marketing as they imply that the firm extends the scope of marketing to cover the whole process of customer management and not just developing new offerings and creating brand awareness.

Service as a perspective implies a shift from value as embedded in products and exchange-value to (co-)creation of value and value-in-use (Grönroos, 2008; Grönroos, 2011; Vargo \& Lusch, 2008). Therefore, a service perspective represents a deep shift in the view of business and economic exchange in general-a shift from goods provision to reciprocal service provision. Even if both service logic and S-D logic are seen to be customer-centric, they differ somewhat in their perspective on value creation. Their differences can be revealed in the 10 foundational promises (FP) that S-D logic are built upon, originally printed in 2004 (Vargo \& Lusch, 2004), but then revised in an article from 2008 (Vargo \& Lusch, 2008). Six of the 10 foundational promises concern value creation and cocreation, and it is especially these that have been criticized by Service logic scholars (Grönroos, 2011; Grönroos \& Voima, 2013; Heinonen, Strandvik, \& Voima, 2013). See Table 6. 


\begin{tabular}{|c|c|c|}
\hline $\begin{array}{l}\text { Foundational promises (FP) to } \\
\text { value creation according to S-D } \\
\text { logic (Vargo \& Lusch, 2008) }\end{array}$ & $\begin{array}{l}\text { Critic of S-D Logic FP (Grönroos, } \\
\text { 2011) }\end{array}$ & $\begin{array}{l}\text { Revised Foundational promises } \\
\text { according to Service logic } \\
\text { (Grönroos, 2011) }\end{array}$ \\
\hline $\begin{array}{l}\text { FP } 1 \text { - Service is the fundamental } \\
\text { basis of exchange }\end{array}$ & $\begin{array}{l}\text { Service is not a one-sided activity; } \\
\text { instead it is a mediating factor that } \\
\text { aims to generate value for all } \\
\text { parties involved }\end{array}$ & $\begin{array}{l}\text { Reciprocal value creation is the } \\
\text { fundamental basis of business, } \\
\text { with service as a mediating factor }\end{array}$ \\
\hline $\begin{array}{l}\text { FP } 3-\text { Goods are a distribution } \\
\text { mechanism for service provision }\end{array}$ & $\begin{array}{l}\text { Not only goods, but other } \\
\text { resources as well. }\end{array}$ & $\begin{array}{l}\text { All resources and processes are } \\
\text { distribution mechanisms for } \\
\text { service provision, however without } \\
\text { including value in themselves }\end{array}$ \\
\hline $\begin{array}{l}\text { FP } 6 \text { - The customer is always a co- } \\
\text { creator of value }\end{array}$ & $\begin{array}{l}\text { Co-creation is only the case when } \\
\text { the customer is direct involved } \\
\text { with other parties. }\end{array}$ & $\begin{array}{l}\text { Fundamentally, the customer is } \\
\text { always a value creator }\end{array}$ \\
\hline $\begin{array}{l}\text { FP } 7 \text { - The firm cannot deliver } \\
\text { value, but only offer value } \\
\text { propositions }\end{array}$ & $\begin{array}{l}\text { The firm can go beyond value } \\
\text { propositions in the case of direct } \\
\text { interaction (co-creation) }\end{array}$ & $\begin{array}{l}\text { Fundamentally, the firm is a } \\
\text { facilitator of customer value. } \\
\text { Provided that the firm can engage } \\
\text { with its customers' value-creating } \\
\text { processes during direct } \\
\text { interactions, it has opportunities to } \\
\text { co-create value jointly with them } \\
\text { as well. The firm is not restricted to } \\
\text { offering value propositions only, } \\
\text { but has an opportunity to directly } \\
\text { and actively influence its } \\
\text { customers' value creation as well. }\end{array}$ \\
\hline $\begin{array}{l}\text { FP 9-All social and economic } \\
\text { actors are resource integrators }\end{array}$ & No critique & $\begin{array}{l}\text { All social and economic actors are } \\
\text { resource integrators }\end{array}$ \\
\hline $\begin{array}{l}\text { FP } 10 \text { - Value is always uniquely } \\
\text { and phenomenologically } \\
\text { determined by the beneficiary }\end{array}$ & $\begin{array}{l}\text { Incomplete premises. Value is not } \\
\text { only determined but also } \\
\text { experienced by the customer }\end{array}$ & $\begin{array}{l}\text { Value is accumulating throughout } \\
\text { the customer's value creating } \\
\text { process. Value is always uniquely } \\
\text { and both experientially and } \\
\text { contextually perceived and } \\
\text { determined by the customer }\end{array}$ \\
\hline
\end{tabular}

There are some notable differences between S-D logic and service logic. First, in FP 7, Grönroos (2011, p. 295) argued that the, "firm is not restricted to offer value propositions only but is also able to directly and actively influence the customers' value creation as well". This opens up for the firm to actively integrate resources in the customer's process.

Second, in service logic there is a distinction between the interaction of co-creation and coproduction. While co-creation is the reciprocal process of creating in a process of direct interaction vis-à-vis value-in-use and the user's consumption process, co-production is when customers 
collaborate in the production of the offering itself (Grönroos \& Gummerus, 2014; Grönroos \& Ravald, 2011; Lusch, Vargo, \& O'Brien, 2007).

Third, while S-D logic treats the customers as value co-creators (Vargo \& Lusch, 2008), service logic argues that the customer is always the creator of value-in-use, and the role of the firm is to facilitate this by providing resources. Eventually, the firm can interact directly with the customer and then become a co-creator of value (Grönroos, 2011). Hence, co-creation has different meanings in S-D logic and service logic; in this thesis, the service logic approach is used.

\subsection{Summary of theoretical background and a base for further understanding}

Service innovation has its roots in research that historically has focused on technology in manufacturing firms (Drejer, 2004). This has led to service innovation research focusing on the produced output in terms of new value propositions. However, service logic offers another lens of understanding through its focus on the customer as the value creator and the integration of resources from multiple actors. A service logic emphasizes the co-creative role of the service process. Firm-centric approaches do not emphasize the customer as the creator of value enough. However, service innovation research that uses a service logic perspective is still in its infancy (Mele et al., 2014).

Emerging literature suggests that service innovation is not limited to the development of offerings per se; instead service innovation is seen as the creation of customer value through integration of resources. Hence understanding how value is co-created is a key to understanding service innovation (Edvardsson \& Tronvoll, 2013). Spohrer et al. (2009) also suggested that, in addition to proposal development, implementation is a central service interaction activity. However, research has only recently started to explore and conceptualize service innovation as a process that supports customer value creation through realization (Bledow et al., 2009; Lusch \& Nambisan, 2015; Siltaloppi \& Toivonen, 2015). Extant literature does not provide much research on realization phase characteristics.

Through direct interaction with the customer, the firm can contribute as a co-creator in the service innovation process and hence not just be responsible for developing value propositions. Extant literature on service innovation has pre-dominantly seen the customer as a source of knowledge that can be used in the internal development process and the launch and delivery has been seen as the end-point of service innovation activities (Alam, 2006; Nijssen et al., 2006). However, expanding service innovation to also include realization enables a closer focus on the customer's value creation; hence, a service logic approach can be beneficial to analyze the service innovation process further. 


\section{RESEARCH METHODOLOGY}

First I will introduce how this work has emerged over five years, followed by a description of the methods employed herein. This section also addresses research validity and reliability. My ambition with this thesis has been to extend the theoretical understanding of service innovation research, especially vis-à-vis realization.

\subsection{Research process and approach}

I started my research with a systematic literature study on service innovation and new service development that spanned marketing, innovation, management, and service literature. Simultaneously with the literature reading, I was involved in a research project with six global manufacturing firms that all were infusing services into their product-dominating offering. My participation yielded research design insights. After defining a broad framework and a direction for the study, I started to figure out the proper research approach and research design. I did consider different methods, but since the study was explorative in nature, I chose qualitative methods and a case study.

My iterative research has constantly tested empirical insights. In this sense, my approach was neither purely deductive nor inductive, but rather similar to the abductive approach (Dubois \& Gadde, 2002; 
Järvensivu \& Törnroos, 2010). Since my research primarily was exploratory rather than confirmatory, the abductive approach, which accepts existing theory and is less theory-driven, is preferable. Further, the systemic combining approach implies a focus on refining existing theories rather than building new ones.

The research design dovetailed with Alvesson and Kärreman (2011), who claimed that the interplay between empirical material and theory is about seeing the former as a source of inspiration and a guide rather than the "ultimate validator for knowledge claims" (Ibid, p. 15; see Figure 2). For example, after conducting interviews, I received new insights into how present theories and models can be understood, which inspired further investigation of both theory and empirics.

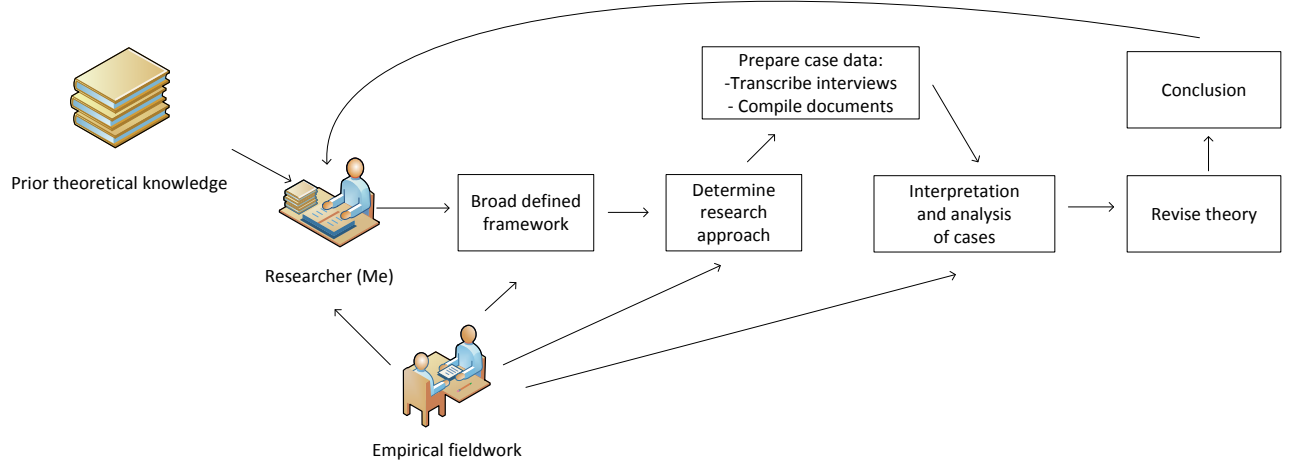

FIGURE 2 RESEARCH PROCESS

\subsection{The research projects}

During my time as a doctoral candidate, I have been a part of two major research projects involving both industrial and academic partners that have been beneficial for discussing ideas with firm representatives, but also as a mean of accessing data through interviews with firm representatives. See Figure 3.

Research project 1, 2010-2012: Including Firm A, B, \& C
Research project 2, 2013-2014:

Including Firm D and its customers and

dealers

\section{FIGURE 3 RESEARCH PROJECTS WITH MY PARTICIPATION}

At the time I joined the first project in June 2010, it had already been running for three months. The project was financed by the Swedish Governmental Agency for Innovation Systems (Vinnova) and involved six global manufacturing firms in different industries; industrial gas, construction equipment, industrial equipment, and industrial robots. The name of the project was "Flexkraft" and concerned how to develop flexible business solutions that sustain competitiveness. All the firms though at different degrees - had started infusing service in their traditional product business and 
were selling these solutions on the global or Nordic markets. One of the firms had worked with services for more than two decades. The project's impetus was the commoditization and low-cost competition that require differentiation through services. This transition is often problematic and not fully understood (Jacob \& Ulaga, 2008; Matthyssens \& Vandenbempt, 2008; Oliva \& Kallenberg, 2003). I was mainly active in a sub-project that discussed co-creating service innovations. Innovation, and especially service innovation, emerged as an area of interest from my side; fortunately there was an interest also from the participating firms. The second project involved a Sweden-based manufacturer of lawn mower and other equipment for gardening firms, and was also financed by the Swedish Governmental Agency for Innovation Systems (Vinnova). In addition to the focal firm, this project also included its customers and business-to-business dealers.

\subsection{Methods}

Initially, the case study method was chosen in order to capture rich data from the firms in the study. Subsequently, interesting cases, in terms of innovation projects, among the firms were selected to support analyzing service innovation and realization. Interviews were chosen as the main method, but also other methods for obtaining empirics where used (observations, workshop). Finally, the data where transcribed, analyzed within-case and cross-case(Yin, 2009).

\subsection{Qualitative case study research}

This research used a qualitative approach and focused on service innovation and realization. In this study, the starting place was the phenomenon of realization in service innovation. A service innovation framework was developed that represented how service innovation and, especially, realization can be understood in manufacturing firms. I used empirics to direct the research and also to strengthen reasoning. Proponents of the case study approach (Eisenhardt, 1989; Yin, 2009) believe strongly in the ability of data and empirics to develop theory incrementally, and conducting case studies with qualitative research methods (interviews, documents, and observation) typically yields a deluge of data that needs to be systematically analyzed.

This study is explorative as little previous research has addressed implementing service innovations in a manufacturing context. For this reason, a case study approach was chosen (Eisenhardt, 1989) since it aims to study a phenomenon within its context rather than independent of it (Gibbert et al., 2008). I have also been able to study the case and its context over time which is beneficial since findings are not necessarily stable (Weick, 1989).

\subsection{Case selection}

In this thesis, the four firms used for data gathering have been the main focus. In addition to this empirical core, seven customers and six dealers for one of the firms have been involved in the study. Since Eisenhardt and Graebner (2007) argued that multiple case studies offer stronger analytical power than single case studies, I have used data from all these firms.

I used different criteria to choose the most relevant case firms. All were part of a research project addressing various service-oriented issues, including service innovation. A firm was chosen in accordance with theoretical sampling (Glaser \& Strauss, 1967), that is, the firm developed services in addition to their products and that they also emphasized customer process and use in relation to 
service innovation. This is in line with Eisenhardt and Graebner (2007), who emphasized the importance in theoretical sampling of case suitability. The following aspects were important when choosing the four firms in this thesis:

First, the participating firms should all be striving to increase their service business in combination with products so that specific innovation projects could be used for empirical data. As a result, selected firms had to provide service innovation aspects with rich information (Eisenhardt \& Graebner, 2007; Yin, 2009).

Second, selected firms were required to submit to interviews and provide documents. In each project and firm, interviewee choice was guided by the aim of understanding the service innovation projects and the process of involving other actors and contributing to customer's value creation.

Third, all the firms needed to show interest in customers' contribution to their service innovation process. In addition, the firm needed to express a need to work with several actors in the network, including, for example, dealers and other intermediaries (this was especially the case with Firm D). In relation to this, customers and dealers themselves needed to show an interest of participating in the project by providing interviews and relevant documents if needed.

Fourth, vis-à-vis the service innovation context, manufacturing firms were valuable as they typically provide a range of services, both advanced and basic. Further, manufacturing firms also provide combinations of products and services, sometimes called hybrid offerings (Ulaga \& Reinartz, 2011), and interact with different frequency with their customers, typically demanding implementation efforts from both the customer and the provider. Thus, manufacturing firms seem to exhibit the characteristics needed for a study of exploring service innovation and realization. In Table 7, the case firms are described in summary.

Selecting the firms and suitable innovations projects was followed by selecting relevant employees to interview. I initially searched for service managers that could provide an overview of how the firm worked with new services. I also looked for subjects that were placed in customer facing units (for example field service organization and sales since they typically interfaced with customers). In the last case, Firm D, customers and dealers were interviewed since they were test firms of the new offering with sensor-based services. In particular, fleet managers and firm owners were interviewed. 


\begin{tabular}{|c|c|c|c|c|}
\hline & Firm A & Firm B & Firm C & Firm D \\
\hline Employees & 28,000 & 1,500 & 40,000 & 14,000 \\
\hline Turnover & USD 8 billion & SEK 3,8 billion & SEK 64 billion & SEK 30 billion \\
\hline $\begin{array}{l}\text { Market } \\
\text { presence }\end{array}$ & $\begin{array}{l}\text { Approx. } 100 \\
\text { countries globally }\end{array}$ & $\begin{array}{l}\text { Approx. } 8 \text { countries } \\
\text { in northern Europe }\end{array}$ & $\begin{array}{l}\text { Approx. } 130 \\
\text { countries globally }\end{array}$ & $\begin{array}{l}\text { Approx. } 43 \\
\text { countries globally }\end{array}$ \\
\hline $\begin{array}{l}\text { Type of } \\
\text { industry }\end{array}$ & $\begin{array}{l}\text { Industrial } \\
\text { equipment }\end{array}$ & Industrial gas & $\begin{array}{l}\text { Industrial } \\
\text { equipment }\end{array}$ & $\begin{array}{l}\text { Gardening } \\
\text { equipment (lawn } \\
\text { mowers etc.) }\end{array}$ \\
\hline $\begin{array}{l}\text { Typical } \\
\text { service } \\
\text { innovation } \\
\text { projects }\end{array}$ & $\begin{array}{l}\text { - Service-level } \\
\text { agreements } \\
\text { - Remote service } \\
\text { - Proactive } \\
\text { maintenance }\end{array}$ & $\begin{array}{l}\text { - Process } \\
\text { optimization } \\
\text { - Online tools } \\
\text { - Training } \\
\text { - Proactive } \\
\text { maintenance }\end{array}$ & $\begin{array}{l}\text { - Process } \\
\text { optimization } \\
\text { - Training } \\
\text { - Condition } \\
\text { monitoring } \\
\text { - Proactive } \\
\text { maintenance }\end{array}$ & $\begin{array}{l}\text {-Sensor based } \\
\text { services } \\
\text {-Training }\end{array}$ \\
\hline
\end{tabular}

\subsection{Data collection}

Information sources included interviews, observations, workshops, and documents.

Interviews. Several interviews were conducted in each case to understand the firm's efforts in service innovation and realization. The interviews can be seen as my main method used to gain knowledge about the empirical context. I conducted the interviews individually and in focus groups, working either alone or with one or two colleagues. Before each interview, I prepared a semi-structured protocol with questions to cover relevant areas and the identified research gaps. Although protocol was not rigid in the sense that I often let the interviewees speak of surrounding topics and I also tried to formulate open questions, informants still may have represented the view they believed the firm wanted to provide (Alvesson, 2011). The interviews lasted between 30 minutes up to three hours, with a typical length of about 45 minutes. In total, 41 persons were interviewed. Four of the interviews were conducted without my personal presence; however, I have been involved in the construction of questions for all the interviews. The interviews were conducted in Sweden and The Netherlands. While the Swedish interviews were conducted in Swedish, the Dutch interviews were conducted in English. Since the rest of research has been done in English, quotes and excerpts have been translated and edited. 
Observations. In order to assess value-in-use for one of the innovative sensor-based solutions, I followed two customer operator for one day (6 hours) at two separate locations. This gave me an opportunity to ask real-time questions when problems emerged. In order to visualize the insights from the observations, a professional artist drew sketches, illustrating different value-in-use issues and problems. This was an idea from the case firm to better understand the customer's daily business. Also, the visualizations could show positive aspects of the use of the new sensor-based solutions. All the sketches were saved in an online folder, enabling the rest of the participants to discuss what happened during one day in the customer's business.

Workshops. In addition to the interviews, and to increase the trustworthiness of the research, halfday to full-day workshops were arranged that typically involved the firm representatives in the research project (6-12 persons). These persons were typically senior service managers and during the workshops both researcher and firm representatives contributed actively to the discussion. However, two workshops with Firm D involved customers, employees and dealers from different countries. The workshop gave both researchers and firm representatives the opportunity to reflect upon the actual topic and also about the direction of the process.

Documents. Documents that were used both internally (for example, strategy documents, policies, and organization charts), and externally (for example, web pages and catalogues) compiled information about the firms. The firms' willingness to provide documents was, in general, good; also, documents regarding sales protocols of specific products were provided. Table 8 summarizes the data in the research process. 


\begin{tabular}{|c|c|c|c|c|}
\hline Firm & Service innovation focus of study & Interviews & Observations & Workshops \\
\hline A & $\begin{array}{l}\text { - Remote service and service based } \\
\text { contracts . Aims to reduce } \\
\text { downtime with up to } 50 \% \text { through } \\
\text { technical support, remote online } \\
\text { support, and preventive } \\
\text { maintenance. Through access to } \\
\text { error log, firm-engineers can } \\
\text { identify cause to failure. }\end{array}$ & $\begin{array}{l}9 \text { persons in } \\
\text { total; } 3 \text { service } \\
\text { managers, } 2 \\
\text { service } \\
\text { developers, } 1 \\
\text { local service } \\
\text { manager, } 2 \\
\text { service } \\
\text { salespersons, } 1 \\
\text { service } \\
\text { technician }\end{array}$ & -- & $\begin{array}{l}2 \text { (customer } \\
\text { involvement in } \\
\text { service innovation) }\end{array}$ \\
\hline B & $\begin{array}{l}\text { - Process optimization services in } \\
\text { welding and metallurgy processes. } \\
\text { Offer's gas saving and optimization } \\
\text { of welding and cutting processes. } \\
\text { Also advisory consultancy to find } \\
\text { relevant methods to optimize a } \\
\text { customer's welding process. }\end{array}$ & $\begin{array}{l}10 \text { persons in } \\
\text { total; } 5 \text { service } \\
\text { managers, } 4 \\
\text { service } \\
\text { developers, } 1 \\
\text { senior advisor } \\
\text { and former } \\
\text { manager }\end{array}$ & -- & $\begin{array}{l}3 \text { (service innovation } \\
\text { in manufacturing, } \\
\text { service productivity, } \\
\text { customer } \\
\text { involvement) }\end{array}$ \\
\hline C & $\begin{array}{l}\text { - Customer process optimization } \\
\text { through for example remote } \\
\text { support, training, preventive } \\
\text { maintenance and design } \\
\text { improvements to increase } \\
\text { availability and reliability for } \\
\text { customer. }\end{array}$ & $\begin{array}{l}7 \text { persons in } \\
\text { total; } 4 \text { service } \\
\text { manager, } 1 \\
\text { quality } \\
\text { manager, } 1 \\
\text { service } \\
\text { developer }\end{array}$ & -- & $\begin{array}{l}1 \text { (service } \\
\text { development in } \\
\text { manufacturing firms) }\end{array}$ \\
\hline D & $\begin{array}{l}\text { - Sensor-based contracts for } \\
\text { handheld machinery. Sensor } \\
\text { equipment is mounted on } \\
\text { handheld equipment in order to } \\
\text { measure machine condition and } \\
\text { thereafter help the customer to } \\
\text { improve its operations. }\end{array}$ & $\begin{array}{l}15 \text { persons in } \\
\text { total; } 8 \\
\text { customers } \\
\text { (owners and } \\
\text { fleet managers), } \\
7 \text { dealers }\end{array}$ & $\begin{array}{l}2 \text { participative } \\
\text { observations } \\
\text { at } 2 \text { customers } \\
\text { (cemetery and } \\
\text { gardening } \\
\text { firm) }\end{array}$ & $\begin{array}{l}10 \text { (involving network } \\
\text { in innovations, } \\
\text { service productivity, } \\
\text { realization in service } \\
\text { innovation, } \\
\text { understanding } \\
\text { customer needs in } \\
\text { value propositions } \\
\text { development) }\end{array}$ \\
\hline
\end{tabular}




\subsection{Data analysis}

Analyzing the collected data involved listening to the recorded tapes and transcribing the interviews. Observations and workshops generated a lot of sketches and pictures, and also video-recorded material that helped the following analysis. Understanding case study phenomena contains challenges since they typically involve multiple levels and units of analysis with fuzzy boundaries (Langley, 1999). Analyzing service innovation in the firms where different projects with different scopes were mixed both across and within the firms presented challenges; however, this also provided an opportunity to analyze different service innovation aspects that are concealed when phenomena are strictly predefined. However, the data were transcribed and then thematically categorized in order to understand different aspects of service innovation. For example, interviews that concerned involvement from customers were gathered, while interviews or parts of interviews that discussed other key areas where categorized and matched with theory, hence the matching of theory was an continuous process in order to direct the study (Dubois \& Gadde, 2002). The analysis of the cases was first done in-case and then cross-case between the different cases. It is difficult to say that data collection and analysis were done sequentially as both activities were conducted simultaneously and tentative conclusions already started to grow during the interviews, which is typically the case in qualitative research (Gummesson, 2005). Hence, data collection and data analysis were intertwined.

\subsection{Evaluation of methodological approach}

Validity is often used to evaluate research in empirical-social context (Eisenhardt, 1989). High validity is achieved by using methods that do not force interviewees and that ensure respondents are well chosen (Stenbacka, 2001). Validity concerns several dimensions; construct, internal and external (Gibbert et al., 2008).

\subsubsection{Validity and reliability}

Construct validity. This parameter, which mainly refers to data collection, considers how well the results of the study actually reflect reality (Gibbert et al., 2008), or really investigates what it claims to (Dubois \& Gibbert, 2010). Through triangulation, a higher construct validity can be used (Yin, 2009); in addition, the workshops further improved construct validity. Establishing a chain of evidence; from recordings through transcriptions and quotes were given attention. I also examined documents to see whether there was coherence between what the interviews described and the internal policy (Gibbert et al, 2008). In general, the interviewees were in tune with the internal documents and discussion in workshops.

The study generally followed Van de Ven and Johnson's 2006 suggestion to involve practitioners from different functional areas in order to advance theory and practice. As a result, practitioners were involved not only when developing research questions through, for example, workshops, but also during later discussion phases to give feedback on preliminary result. In general, the feedback was positive and often only a matter of some adjustments and rewriting.

Internal validity mainly refers to the data analysis phase and how empirically observed patterns match or mismatch with previous theory and different context. In this study, the empirics and theory 
were matched iteratively. Further, the analysis of the cases included identifying patterns among the different firms. First, within-case analysis were done, followed by cross-case analysis to match patterns across firms.

External validity implies the ability to generalize study results to other contexts (Dubois \& Gibbert, 2008). Although case studies can examine a phenomenon within a context since findings are unstable over time (Weick, 1989), the same characteristic can draw criticism as case studies are situation-specific, and therefore, are not appropriate for generalization (Eisenhardt, 1989). However, since the primary aim of this thesis is not statistical generalizability but understanding, analytical generalization can still be relevant (Yin, 2009).

Reliability. Reliability ensures that the study can be repeated with no random errors (Gibbert et al., 2008). This study employed transparent interview protocols and made transcriptions available to colleagues in order to manage reliability. Further, in order to systematize the literature review (Paper I) the suggested steps by Tranfield et al. (2003), including a review protocol, clear instruction criteria and quality assessment of selected studies, were followed. The narrowing of journal selection to the field of marketing and innovation necessarily excluded many articles, but it was a necessary decision in order to have manageable number of articles to review. All steps in the literature review were thoroughly described and explained in order to allow other researchers to replicate the study (Gibbert et al., 2008). 


\section{SUMMARY OF THE PAPERS}

The following chapter briefly summarizes the five appended papers in the thesis. Three of the papers are published in peer-reviewed journals (I, II, \& III), one is submitted to a journal (IV), and one is a working paper (V). In addition to this summary, the articles in their entirety can be found in the appendices. 


\subsection{PAPER I}

\section{The evolution of service innovation research - a critical review and synthesis}

Carlborg, P., Kindström, D., and Kowalkowski, C.

The Service Industries Journal, 2014, Vol. 34 (5): 373-398.

This paper reviews the emerging service literature from various perspectives, primarily the research fields of marketing and innovation. The paper shows how service innovation is an expanding field that has evolved to cover a greater part of intra-firm activities as well as customer activities. Meanwhile, service innovation has gone from being contrasted with technological innovation to including aspects of both technological innovation and non-technological innovation.

The first article in the sample was published in 1986 (Barras) while the most recent 23 articles were published in 2010. Over these 25 years, the number of published articles addressing service innovation increased steadily, reaching a maximum of 25 in 2009. Though the distribution in different journals has been wide, articles primarily have appeared in innovation and services marketing journals, especially in recent years. Relatively few articles in the sample appeared in major marketing journals, and none were in the leading publications: Journal of Consumer Research, Journal of Marketing, Journal of Marketing Research, or Marketing Science. This pattern could be related to senior marketing scholars' charge that the top journals tend to emphasize incremental theory tests rather than new idea development (Lehmann \& McAlister, 2011; MacInnis, 2011), and these journals may regard service innovation research as an emerging research field. Some of the factors influencing the increased focus on service innovation are the growing interest in services across various industries and the closer links of new topics to the service innovation concept (den Hertog et al., 2010; Toivonen \& Tuominen, 2009). Service innovation is no longer regarded merely as a side activity; rather, it has become a research topic in its own right, accompanied by an increasing focus on major economies, a transformation sometimes referred to as the "servitization of society" (Toivonen \& Tuominen, 2009, p. 897).

Three phases in the service innovation evolution illustrate the literature progression: formation, maturity, and a multidimensional phase. Each show interesting specificities regarding subjects and perspectives, and the focus of service innovation research has shifted throughout its evolution: In the formation phase, the service offering itself was the primary research focus before it evolved to include the customer and form the organization in the maturity phase. Finally, the multidimensional phase featured a much more diversified pattern, emphasizing the linkages between service innovation and business strategy. As the field continues to evolve and the service innovation concept becomes all-encompassing, identifying the exact loci of service innovation research becomes more difficult. This development is driven, among other things, by the service-based economy (Gallouj \& Windrum, 2009), which demands expansive innovation. In the past three decades, major deregulation has occurred across economies in industries such as air transportation, financial 
services, health care, and telecommunications, and paralleled by the emergence of new industries, especially in the information and communication technology field (Fisk, Brown, and Bitner, 1993; Rust and Thompson, 2006). Continuous (and accelerating) technological development is likely to continue to blur the lines between service and manufacturing, enabling further growth, and in turn, more innovation.

Beside investigating and categorizing the various topics during the three phases, this paper also examines leading perspectives discussed by Coombs and Miles (2000). Service innovation research has shifted from an assimilation perspective, in which innovation appeared generic, through a demarcation perspective, which regarded it as something that should be differentiated from product innovation, and finally into a synthesis perspective. The demarcation perspective often has focused on sector-based case studies and typologies, such that it lacks consistency with and adds little to existing innovation theories (Gallouj \& Savona, 2009). By integrating the insights from demarcationoriented research with those gathered from manufacturing-oriented assimilation research, a synthesis perspective offers a unifying, multidimensional innovation approach. This emerging extension is likely to continue as a reflection of the predominant synthesis perspective. For manufacturing firms that add services, this extension implies a reconsideration of their innovation setup toward an approach integrated with product activities (Kindström, 2010). For service firms, an increased focus on extending the innovation concept offers a new framework, not limited to services. Instead, this focus provides opportunities to better understand customer needs and value creation processes through combinations of services and products. 


\subsection{PAPER II}

\section{A lean approach for service productivity improvements - Synergy or oxymoron?}

Carlborg, P., Kindström, D., and Kowalkowski, C.

Managing Service Quality, Vol. 23(4): 291-304.

This paper explores whether lean principles benefiting service is an oxymoron or synergy. The study suggests promising synergies as well as important obstacles for applying lean principles in services. Standardizing services and increasing reliability through lean principles can increase internal, firmlevel efficiency. However, the active role of the customer in certain services along with simultaneous high demand diversity makes it increasingly difficult to apply lean principles. Also, the effects of customer satisfaction must be considered when improving service productivity, otherwise the positive long-term effects of a lean approach in service will be absent.

Previous literature (Anderson et al., 1997; Parasuraman, 2002) emphasized the difficulty of increasing productivity in services without decreasing customer satisfaction because service productivity depends on efficiency (output/input ratio) and customer satisfaction (Parasuraman, 2002). A firm that is downsizing employees may yield economic return in the short term, but risks decreased overall customer satisfaction. Simultaneously achieving efficiency and customer satisfaction has proven especially difficult for services (Anderson et al., 1997). In addition, service productivity is not restricted only to suppliers; customer efforts in time and resources also have an effect (Calabrese, 2012; Geum et al., 2011; Grönroos \& Ojasalo, 2004; Parasuraman, 2002). Previous lean research has not focused on customer efforts to a great extent, which may be a consequence of productivity being a rather firm-centric concept. However, when translating lean approaches into services, customer efforts must be considered because they typically reflect active participation in value co-creation. We postulate that this fundamental difference in the role of the customer will affect how lean principles may be applied in service.

Service research, especially on new service development, has emphasized service quality (Edvardsson, 1997; Edvardsson \& Olsson, 1996; Normann, 2001). Conversely, literature addressing efficiency has implicitly assumed that a lean approach, which reduces the waste of non-value-adding activities and improves efficiency, is the best improvement strategy for organizations striving for market competitiveness and is not restricted to a manufacturing context, but is applicable to any industry (Womack, Jones, \& Roos, 1990). However, critics of this view have noted that lean approaches are context-dependent and not generalizable (Shah \& Ward, 2007). The importance of the context has been largely ignored in the literature and few studies have investigated the suitability of lean approaches in contexts other than high volume and mass production (James-Moore \& Gibbons, 1997). Nevertheless, some important exceptions are concentrated in health care (de Souza, 2009; Landsbergis, Cahill, \& Schnall, 1999) and other service businesses (Bowen \& Youngdahl, 1998). 
This research proposes that lean approaches can improve service productivity. Both efficiency and effectiveness (service quality and customer satisfaction) can be improved if used for proper service types. However, previous research has shown that an increase in efficiency is connected with lower service quality and customer satisfaction (Anderson et al., 1997). Nevertheless, the application of lean approaches holds significant potential for improving productivity in certain types of service offerings. We believe such an approach will become an important part of service innovation in the future. By using Larsson and Bowen's 1989 framework, we argue that service offerings with high demand diversity and active customers exhibit a greater risk of losing customer satisfaction; therefore, application of lean principles to these service types is limited. A lean approach has the greatest potential when the service provider is isolated from the customer, or when the customer produces the service away from the provider. In particular, services with low diversity and customer participation are those where lean principles best can be applied. Differentiating the use of lean principles allows a greater chance that efficiency improvements will not negatively affect customer satisfaction. Therefore, a lean approach to service productivity is not necessarily an oxymoron; its applicability depends on the type of services offered. 


\subsection{PAPER III}

\section{Service process modularization and modular strategies}

Carlborg, P., and Kindström, D.

Journal of Business and Industrial Marketing, 2014, Vol. 29: 313-323

This paper investigates service modularity as an alternative way to improve service productivity and enable service co-creation. Recognizing the role of the customer's competences and activities, this study investigated how service modularity can enable value co-creation.

In many industries, service offerings are becoming more advanced and comprehensive (Kowalkowski, Kindström, \& Brehmer, 2011; Ulaga \& Reinartz, 2011), creating challenges for firms that attempt to balance standardization with customization (Nordin \& Kowalkowski, 2010; Sundbo, 2002). More advanced services tend to be more difficult to standardize because of the relatively higher degree of resource-specific knowledge they demand and their interactive dimensions. Such characteristics prevent economies of scale, and the cost efficiency of service deployment diminishes. Furthermore, the inability to reuse elements of a resource-specific, advanced service offering demands more reinvention, which again increases costs (Böttcher \& Klingner, 2011). Over time, these traits of advanced service offerings affect the profitability and productivity of many firms, especially businessto-business (B2B) service providers.

In this paper, service modularity is conceptualized according to Pekkarinen and Ulkuniemi (2008), including four elements: service modules, process modules, organizational modules, and customer interface modules. Service modules are the smallest service unit which can be offered as itself or as a part of a service offering, creating the customer-perceived value (Rahikka, Ulkuniemi, \& Pekkarinen, 2011 , p. 358). Process modules are standardized, indivisible steps. Organizational modules are resources (team, units, networks) involved in service creation; finally, customer interface modules are process or organizational modules in which the customer interface can be managed effectively (Pekkarinen \& Ulkuniemi, 2008).

An active customer creates a greater need to include resources that derive from that customer. For these services (self-service and interactive services), this study suggests that service providers pay close attention to the customer's process and organizational modules. A successful service deployment requires significant customer action, including employees with specialized knowledge or IT infrastructure. A modular approach to addressing these issues provides a good structure for integrating important customer resources and knowledge into service deployment. On the other hand, the customer can be passive for many reasons (lacking the right competence, poor ability to participate, or the desire for a third party to quality-check the business); in these cases, the service, organizational, and process modules that mainly derive from the provider are of the greatest concern. These services are close to what Grönroos (2011) called the provider's value facilitation, 
such that the services are developed, designed, and delivered without direct customer interactions. Therefore, these service providers can focus on their own processes and how to improve them.

The second dimension of the proposed framework reflects the business focus, which, if centered on supporting the supplier's own products, mainly entails the front office. The processes behind what is visible are less important because they tend to invoke high competition. Instead, the provider must demonstrate the relevance of the service to the customer during the exchange. Bundling service modules into relevant customized service offerings becomes an important efficiency strategy in these kinds of services.

In contrast, a process focus emphasizes the customer's processes, and thus represents a rather different approach, from a modularity perspective. These processes are more critical than what is visible to the customer (service modules). These services are typically more complex and technically advanced than basic services; therefore, they require the contributions of specialized employees from different departments. The need for the right employees parallels the demand for well-defined, robust processes that can support different customers in varying situations. In cases with an active customer, their process and organizational modules join as well, which emphasizes the need to manage the interaction that emerges.

Recognizing the role of the customer and the business focus for different service offerings, this framework offers a modular approach to each setting that specifically covers value co-creation and illustrates an avenue for including customers in service modularity.

Services can be co-created, so service modules should include customer elements. This inclusion increases the complexity of the modules, as well as the potential mutual value. The observation of customer-specific and supplier-specific module sections is an important finding that should lead to further developments of service context modularity. 


\subsection{PAPER IV}

Triadic Value propositions: When it takes more than two to tango

Kowalkowski, C., Kindström, D., and Carlborg, P.

Submitted to Service Science, January 2015

As manufacturers initiate service-led growth, their interdependence with intermediaries and users increases. Previous research mainly focused on dyadic interdependencies between manufacturer and customer; however, this study also involves a third actor (intermediary or dealer), which increases service-led growth complexity. In this study, we conceptualize a mutually dependent triadic value proposition, and analyze how it changes structurally, economically, and socially vis-à-vis manufacturers, dealers, and users when the former enters the service market.

The research is based on a longitudinal, five-year study of a global industry incumbent entering the service business by offering a new sensor-based service for B2B users. Primary data comes from interviews with respondents from the manufacturer, dealers, and end-users in the Netherlands, Sweden, and the US. What makes the context and time particularly interesting to study from a value proposition perspective is that (1) the dealers sell multiple brands and have no specific loyalty towards a particular manufacturer as often is the case concerning expensive machinery products, and (2) entering the service market implied a redefinition of the existing relationship and value proposition characteristics in order to succeed. Both these aspects offered an opportunity to explore how triadic value propositions are formed when a manufacturing firm enters the service market with an offering that is based on both products and services.

Results show how the dynamics of the triadic value proposition throughout the entire service development process evolve; from idea and concept to launch and sales. Modifications and adaptations take place due to factors such as emergent opportunities, unexpected limitations, and internal strategic re-prioritizations, as well as inputs from dealers and customers. By analyzing how the proposition evolves over time, we can better understand how to involve and collaborate with key actors in order to initiate a disruptive change on a firm and network level. This is particularly timely given the major difficulties related to service infusion when intermediaries play a decisive role for success. 


\subsection{PAPER V}

\section{Who involves Whom? Interaction modes in service innovation}

\section{Carlborg, P.}

Working paper

Collaboration and involvement of other actors' resources are surfacing as a key issue for service innovation. Although network resources have been emphasized, research nonetheless tends to focus one-sidedly on the involvement of customer resources in the firm's development of the offering per se and hence foresee the firm's involvement in service innovation realization. Therefore, the purpose of this study is to analyze both firm and customer resource involvement in service innovation.

The study used an exploratory case study approach, focusing on two Swedish B2B manufacturing firms that have added services to their core product offerings (service infusion). Data was collected through interviews and focus groups.

Firms and customers, to varying degrees, both contribute resources to service innovation realization. The study identifies four firm-related resources and three customer-related resources that are used in the service innovation process and finds that different types of offerings are related to varying key resources. Based on different levels of involvement, a typology of interaction modes is developed.

The findings have several important implications for service managers. First, even if a firm's value proposition is developed together with the customer or group of customers, it is also beneficial to consider the firm's involvement in the customer's value creation as a part of the service innovation process. However, the degree and type of involved resources depend on the type of value proposition.

Second, increased and more specific knowledge of the customer's resources is required in order to determine what resources the customer and the firm should contribute vis-à-vis value proposition development.

Previous literature tends to focus on how the customer can be involved in the firm's creation of value propositions. This article suggests that the literature should also include the customer's creation of value associated to the value proposition and the firm's involvement in this process. Hence, the study contributes to the exploration of the important link between the development of offerings and the practical realization of the offerings. 


\section{DISCUSSION AND RESEARCH FINDINGS}

This section discusses the thesis' main findings. Rather than repeat or replace the discussion in the appended papers, the following chapter extends and frames their discussions.

\subsection{Extending the service innovation framework}

Previous service innovation research has primarily been focused on the pre-launch process (for example, design, analysis, development) and the outcome in terms of new value propositions (Froehle \& Roth, 2007). Also, service innovation research that has included implementation has tended to perceive it as the delivery of the offering and hence approaches the customer as a mere passive receiver (Singh, Panesar, \& Markeset, 2008). In contrast, this thesis starts from the service logic approach, focusing on how value is created by customer (see for example, Edvardsson \& Tronvoll, 2013; Lusch \& Nambisan, 2015; Ordanini \& Parasuraman, 2011; Rubalcaba et al., 2012).

In this study, realization is divided into two phases: deployment and post-deployment. Deployment denotes that the realization process is not limited to physical goods as the commonly used term "delivery" or "implementation" may indicate (see for example Scheuing \& Johnson, 1989). Instead, deployment refers to a broader spectra of both tangible and intangible resources. For example, consultancy services can be seen as deployed and supportive of value creation in the customer's 
process (hence it is the human resources that actually are integrated in the customer's environment). This reflects the diversity in offerings from many manufacturing firms that increasingly support their customers through a combination of tangible and non-tangible resources.

When the needed resources, related to the value proposition, are integrated in the customers' processes, realization begins; that is, when the customer can start to create value-in-use derived from the value proposition. In this sense, the value proposition only symbolizes a potential value, a proposal, or a promise for the customer (Frow et al., 2014). However, realization translates the value proposition into value-in-use for the customer through deploying resources from both firm and customer. Both development of value proposition and realization are intertwined (Bledow et al., 2009), and since the same value proposition can lead to different value-in-use based on different environmental factors, managing and controlling realization is an integral part of service innovation (Bledow et al., 2009; Hargrave \& Van de Ven, 2006).

Approaching service innovation as a process wherein firm and customer together seek ways to collaborate in resource integration and value creation, provides a wider scope of analysis in line with the service logic approach (see, for example, Grönroos, 2011). The following analysis outlines the different parts of service innovation realization (that is, deployment and post-deployment), illustrating resources involved and firm and customer interaction patterns. Empirical examples from the four case studies contribute to the understanding of the extended service innovation framework in the following section. See Figure 4.

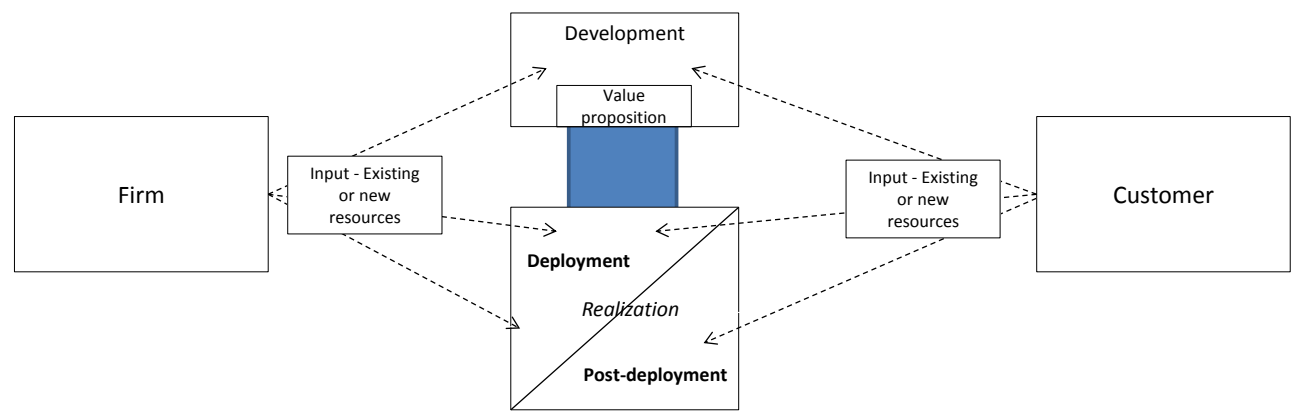

FIGURE 4 SERVICE INNOVATION FRAMEWORK

\subsubsection{Realization characteristics}

Deployment. The analysis of the cases shows that service innovation realization starts with integrating the developed value proposition into the customer's business, that is, deployed or taken into use. This can, for example, be integration of human resources into a process expertise service (as in Firm B process optimization case), or it can be integration of both physical and human resources through a sensor-based service (Firm C and D-case). Previous research has acknowledged the important link between value proposition development and the actual deployment process (Toivonen \& Tuominen, 2009), in order to support the customer's creation of value-in-use. However, considering the deployment as an extension of service innovation implies that the firm still has a role 
in the process, as it still can directly or indirectly influence the customer's value creation (Grönroos, 2011).

In order to support the customer in the realization phase, it becomes important for the firm to understand the value proposition's functionality (that is, that resources are integrated correctly in accordance to the proposal) but also its usability (that is, that the customer can create value-in-use in line with the proposal) (Möller et al., 2008; Tuli et al., 2007). The case firms described the importance of understanding the customer's environment and own knowledge in order to know what resources to integrate, but also what is expected from the customer. For example, IT infrastructure was mentioned to be important when integrating sensor-based services and Firm $D$ described that internet connections must be in place in order to gain data from the installed sensors; however, not all customers had that kind of infrastructure at hand which prevented functionality and also usability. Without ensuring such contextual aspects, the customer will find it difficult to use and gain value-inuse as intended (Korhonen, 2014). Hence, not only following the directions from value propositions becomes essential, but also adjusting and refining them.

The case firms showed that different value propositions require different deployment activities and different type of resources to be integrated. For example, for preventive maintenance, no new installation needs to be done; instead, other resources like human resources in forms of skilled employees, need to be integrated. In contrast, sensor-based value propositions, such as in Firm C and $D$, require software, human resources (employee training) and hardware (physical resources) to be integrated in the customer's process. In these situations, Firm C emphasized that they enter the customer's world when deploying value propositions, that is, using the customer's terminology and language to adapt to the their environment.

Through detailed plans, Firm C showed that a "delivery plan" can systematically ensure that right competencies from both firm and customer are at hand in service innovation realization. Firm $\mathrm{C}$ emphasized that deploying value propositions required skills throughout the entire organization. Since customer knowledge was needed in order to adequately support creating value-in-use, skilled employees that knew customer processes were desirable, as well as the technical support that gathered and enabled this information. However, detailed plans for service innovation realization need to be balanced with the ability to take alternative actions if unforeseen occasions occur (Bledow et al., 2009). For example, since contact with the customer environment typically implied revision of the value proposition in order to fit with their customer processes, a different focus is needed in the deployment phase; for human intensive services, related to the skills of customer facing units (for example the field service organization, the focus is on having the right competencies of the employees and how they can work in different environments as problem-solvers, thus extending the firm's R\&D department. However, these service innovation streams that are driven by the frontline employees (for example, field service organization) also need to be coordinated by management so that a certain degree of reproducibility will be achieved (Gebauer et al., 2008). With unclear responsibilities, for example, weak coordination internally and with customers, for service innovation (R\&D, customer facing units, marketing), there is a potential risk that the service innovation does not create new value for customers and becomes expensive for the provider (Dörner 
et al., 2011). Hence, managing both a top-down process (strategy-driven) that coordinates and develops new concepts and a bottom-up process (employee-driven) that works with realization and finds solutions to emerging problems in the customer's process, becomes important to balance the extended service innovation process. Paper III provides a framework for modularization that can build up more complex services and hence offer a way to also coordinate and reproduce employeedriven service innovation initiatives.

Post-deployment is included in realization because the innovation process may extend as long as the relationship between the customer and provider continues. While deployment denotes the initial integration of resources into the customer's business, post-deployment focuses on the period after the initial integration in response to emerging customer requirements (Tuli et al., 2007). The cases, in line with previous literature, show that customers are interested in solving problems over time (Tuli et al., 2007). Services can, for example, focus on operating and maintaining a system during its life cycle (Davies et al., 2007), and hence post-deployment denotes an ongoing service innovation process. For example, if the customer is interested in a long relationship that aims to improve a paper factory's efficiency, as in Firm C, the post-deployment phase requires employee training and also time-consuming mindset and working practice shifts. Since Firm $\mathrm{C}$ is working with customers in order to facilitate their development by optimizing long-term resource usage, realization can be seen as containing a post-deployment phase in addition to initial deployment activities.

Hence, post-deployment activities in the realization phase of service innovation are related to the support of the customer during the life-cycle of the service. Therefore, the firm needs strong customer facing units (for example, field service organization and customer training resources) and application knowledge. In addition, also business knowledge of the customer is required in order to know what is important for the customer do develop; for example knowledge of important customers to the customer and what they require from the customer is important in order to help the customer to develop and grow.

New technology enables potential opportunities to monitor customer operations remotely for long periods of time; hence, the use of ICT to analyze data is critical for post-deployment activities. New technology also implies that more ICT-based service innovation enables the customer to perform their own activities and, hence, the firm can have a less-pronounced role (for example, support the customer when technology fails). Hence, ICT is an important service innovation enabler (den Hertog et al., 2010). Firm C's service of operator-driven reliability is an example of this where new technology and tools enable the customer to perform process inspections, minor adjustments, and observations of machine performance through hand-held devices. Post-deployment requires deeper understanding of how the customer is gaining revenue and what that is important to optimize in their process. Table 9 presents a short summary of deployment and post-deployment characteristics of realization. 


\begin{tabular}{|l|l|}
\hline \multicolumn{2}{|c|}{ Realization } \\
\hline Deployment & Post-deployment \\
\hline $\begin{array}{l}\text { Innovation focus: Initial integration of resources } \\
\text { into the customers' process. Understanding } \\
\text { customer need is critical. }\end{array}$ & $\begin{array}{l}\text { Innovation focus: On-going process over a life- } \\
\text { cycle period. Understanding customer need and } \\
\text { how they evolve is critical. Understanding the } \\
\text { customer's business. }\end{array}$ \\
$\begin{array}{l}\text { Managerial issues: Coordinating strategy (top- } \\
\text { down) with employee initiatives (bottom-up) }\end{array}$ & $\begin{array}{l}\text { Managerial issues: Coordinating strategy (top- } \\
\text { down) with employee initiatives (bottom-up) and } \\
\text { Key resources: Customer facing units, application } \\
\text { knowledge }\end{array}$ \\
$\begin{array}{l}\text { customer initiatives } \\
\text { Key resources: Customer facing units, application } \\
\text { knowledge, customer resources }\end{array}$ \\
\hline
\end{tabular}

\subsubsection{Productivity improvements as part of service innovation}

Many times, service innovation is ad hoc as a response to a customer's need, or incremental and diffuse (Berry, Parish, Cadwallader, Shankar, \& Dotzel, 2006; Gallouj \& Weinstein, 1997), which can be costly for the firm. Meanwhile, customers typically demand services for reducing costs in their own operations (Kristensson, Gustafsson, \& Witell, 2014). This enables research that considers the duality of improving both customer and provider efficiency as a part of service innovation. This research suggested that both lean-principles (Paper II) and service modularity (Paper III) can be potential avenues for dealing with heterogenic and rapidly changing customer needs. Hence addressing not only effectiveness (collaboration in order to understand the customer's need), but also the efficient use of both customer and provider resources, is an important aspect of service innovation (Kuusisto et al., 2013).

As innovations typically are driven from the use situation, service innovation also includes improvements through efficient use of resources through a significant or incremental change in how customers create value-in-use (Rubalcaba et al., 2012). Furthermore, Skålén et al. (2014) suggested that changes in practices can be seen as a type of innovation, arguing that practice-based innovation includes, for example, improvements of customer efficiency in the production process through better and novel ways of working. This is exemplified by Firms A, B and C that offer productivity improvements through direct involvement in the customer's processes. Firm A, for example, uses simulation tools and trains the customer in order to become more productive. Firm $\mathrm{C}$ also exemplifies this by showing how a customer that implemented operator-driven reliability could improve overall equipment effectiveness by 2 percent, realizing almost USD 2 million in savings. Hence, productivity improvements as a practice-based innovation are one pivotal part of service innovation. 


\subsubsection{Lean as an example of a new practice}

In line with the concept of improving the customer's efficiency and productivity, Paper II and III are closely connected to realization. Paper II discusses how the integration of a production methodology (lean production) could be beneficial. This is an example of how changes in routines and policies can lead to increased efficiency through better use of resources. Paper II identified how high customer participation potentially neutralizes the productivity improvements since increased efficiency can give lower customer satisfaction. This phenomenon is not new, and Ulaga and Reinartz (2011) emphasized a balance between ensuring efficiency and effectiveness in the deployment of value propositions. Standardizing back office processes and customizing front office processes can be one way of managing the balance. Paper II suggests that the role of the customer must be considered when doing this type of productivity improvements, especially since lean principles are rooted in an internally focused manufacturing context that traditionally sees the customer as rather passive.

\subsubsection{Using a modular approach to service productivity}

According to Grönroos and Ojasalo (2004), service productivity should be considered as a combination of both efficiency and customer satisfaction. By continuously developing the relationship, the value proposition becomes better adapted to the customer's process. Paper III provides insights in how value propositions can be structured and tailored by using a modular approach. Modularizations of offerings serve as a platform for responding to heterogenic customer needs. Also Lusch and Nambisan (2015) argued that service innovation requires a platform, containing a modular structure of tangible and intangible resources that can be bundled for specific customer needs. However, transparency is needed; hence, the modular approach suggested in Paper III can be beneficial. A modular approach can also be seen in the light of Gallouj and Weinstein's "recombinative innovation" (1997), which refers to how service innovation can be initiated through the recombination of existing elements. Since a potential first way to solve a problem is to combine resources that already are available (Gallouj \& Weinstein, 1997), a modular approach to service provision can provide better transparency and facilitate recombinative innovation.

Paper III shows that customer resources are an important contribution to the process, and when the customer is more active, the resources that the firm integrates into the process need to be more flexible. Hence, combining the resources into new, slightly adopted value propositions can be seen as a type of incremental or adaption type of service innovation (Gallouj \& Weinstein, 1997; Skålén et al., 2014). Paper III, and also paper V, discuss how the level of customer knowledge differs; hence, the configuration of which actor contributes what resources needs to be flexible. Since service offering deployment can be costly, a modular approach can be beneficial for both firm and customer (Ulaga \& Reinartz, 2011). However, rationalizing resources too much in the realization phase can actually reduce revenue if the cost reduction leads to decreased customer satisfaction (Rust \& Huang, 2012). Therefore, using a modular approach where activities and resources can be combined offers a strategy for efficient service deployment that maintains customer satisfaction. 


\subsection{Co-creation and service innovation}

Interaction and co-creation between the customer and firm is a key to understand service innovation (Edvardsson \& Tronvoll, 2013). In Figure 4, the interaction that takes place during the development and realization phases is emphasized through arrows that indicate customer and firm engagement. Since different value propositions and different levels of knowledge require different input from the firm and customer respectively, the interaction pattern will look different.

In line with service logic, value is created by the customer and only occasionally the firm act as a cocreator of value (Grönroos, 2011; Grönroos \& Ravald, 2011); this implies that the firm can interact with the customer both directly (as a co-creator) and indirectly (as a facilitator). According to service logic scholars, indirect interaction is between one actor and a standardized system or product without any merged collaborative process, while direct interaction implies a joint process where the actors or intelligent systems work together and the provider can actively influence customer value creation (Grönroos \& Gummerus, 2014). The following analysis will outline indirect and direct interaction in service innovation realization in line with service logic.

Indirect interaction is characterized by the firm's ambition to facilitate the customer's value creation through the provision of resources. Michel et al. (2008b) argued that the customer may want to integrate resources themselves due to increased control, flexibility, privacy, efficiency or savings. For example, Firm C indirectly supports the customer's value creation through preventive maintenance that enables the customer to reduce their down-time in customer-specific applications (see Figure 5). One more example of indirect interaction in service innovation is when the firm contributes with resources for the customer's process where the customer, then integrates the resources into their value-creating process (Grönroos \& Ravald, 2011). In this sense, the firm facilitates its customer with resources that they can then use to create value. For example, Firm A runs a service innovation process where they monitor the robots remotely and perform preventive maintenance, enabling the customer to use the robots without unplanned breakdowns.

Another example is from Firm B which automatized gas supply to laboratories and hospitals so that the customer could operate without disruption. However, the customer still wanted control over the usage of the gas. Representatives from Firm C emphasized that different customers contribute with different efforts, depending on the customer's knowledge and capabilities. Therefore, Firm $\mathrm{C}$ acted flexibly in order to account for customer effort, and each of Firm C's quality plans (that is, a plan that states the contributions from each of the involved actors) distributed effort between customer and provider to secure successful deployment of resources.

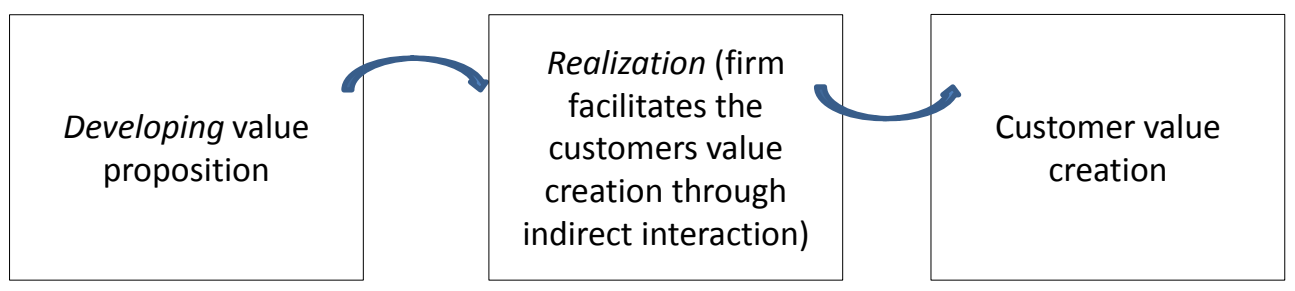

FIGURE 5 INDIRECT INTERACTION IN SERVICE INNOVATION 
Direct interaction concerns the firm's active participation in the customer's value creation process (Grönroos, 2011). Hence, in these cases, the firm and the customer jointly contribute resources in order to transform and integrate them in the customer's process. See Figure 6. For example, Firm B operated with process support services in their customer's value creating processes in the welding industry. In this case, Firm B contributed with expertise and technical resources in order to improve the customer's welding process. The customer also contributed to the process with a continuous dialogue with the firm employees; hence problems were solved jointly and with interacting resources from both firm and customer. Through this joint process, Firm B and the customer can, in collaboration, find a proper method and approach to optimize the welding and cutting process. Another example is from Firm $\mathrm{C}$, which offers operator-driven reliability via advanced wireless technology for inspection of machinery and machine performance. The last example is from Firm $D$, and their development of a sensor-based service to be mounted on their hand-held equipment for professional users. While Firm D identified many potential advantages with the sensor-based service, the customer had some installation problems. Since the dealer that was supposed to assist the customer lack the proper knowledge, Firm $D$ needed to be involved in the actual usage of the equipment. In this case, Firm $D$ went from being a facilitator of the new sensor base service, to becoming a co-creator together with the customer and supported the customer with managing the analysis of the information gained (for example, how to use the machinery, the need to change equipment and training of employees). One customer did the analysis together with Firm $D$ and realized that all their equipment was poorly adapted to the context (small area for gardening), and realized that they had to buy a new fleet in order to improve efficiency (better use of products) and improve the employee safety (better adapted machinery).

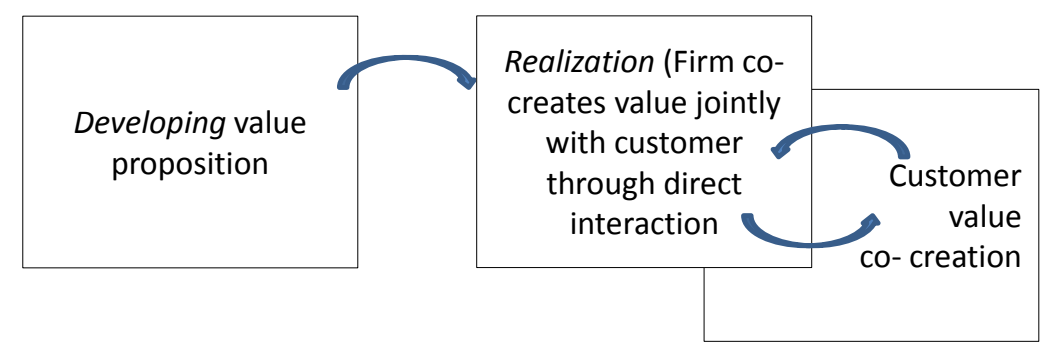

FIGURE 6 DIRECT INTERACTION (VALUE CO-CREATION) IN SERVICE INNOVATION

Interaction is primarily discussed from a dyadic perspective involving firm and customer. However, Paper IV discusses service innovation that involves a third actor (intermediary or dealer) and emphasizes the importance of interaction (both indirect and direct) at different levels. Structural ties imply connections to institutional bonds, technical ties can enable information exchange, and social ties can ensure long-term stability (Holmlund \& Törnroos, 1997). Thus, interactions in service innovation with the dealer in different dimensions can be seen as a good resource instead of a "necessary evil". Involving the dealer as a type of customer and interacting with them in the development of value proposition and also service innovation realization can be beneficial. 
In summary, different customers demand different support based on their various needs, abilities, and level of knowledge and resources. Hence, service innovation is not only employee-driven and strategy-driven from the firm, but also customer-driven (Rubalcaba et al., 2012). Through this, firms need to focus on coordinating not only internal strategy and employees, but also the active customers that contribute with resources to the service innovation process. This implies not only a deep understanding of customers and their needs (Möller et al, 2008; Michel et al., 2008a), but also understanding of the employees' abilities and the combination of firm and customer knowledge and resources. Paper $\mathrm{V}$ introduces a framework that also takes customer contribution into consideration and specifies what resources are especially involved in different interactions (see Paper $V$ for the complete framework). In summary, both direct and indirect interaction (Grönroos \& Voima, 2013), can be seen in service innovation realization. Direct interaction requires a deep knowledge of the customer's processes in order to attend in a joint value co-creation process. Also the level of the customer's knowledge is central for how the interaction is shaped since customers with higher level of knowledge can engage more actively in service innovation.

The four case firms differed in whether their value propositions were directed at the already installed base or at the customers' processes (See Mathieu, 2001). Firm B and C sought to improve the customer processes whether they sold the products or not, while Firm A mainly concentrated service offerings only where they had an installed base. This practice implies that Firm A was more restricted in its performances directed at the customer directly because the installed base was only a part of the customer processes. Here, Firm A involved its resources in order to facilitate the customer's value creation by providing industrial robots with low break-down level, so that the customer can focus on what to do with the production (even though they also provided process optimization through direct interaction with their customers). Meanwhile, Firm B and C offer broader services beyond their installed bases. Since service innovation projects that were connected to co-creation with the customer requires a deep knowledge in the customer's process (Möller et al., 2008), Firm B and $\mathrm{C}$ were in these cases restricted to customer segment where they had a good understanding for the processes. In contrast, when interacting as a facilitator (through indirect involvement) it is mainly the customer that creates value independent on the firm's. However, the resources are still there and support the customer's value creation. See Table 10 for examples from the different firms when they interact indirectly (as facilitators) or directly (as co-creator). 


\begin{tabular}{|l|l|l|}
\hline & Interaction for facilitating (indirect) & Interaction for co-creation (direct) \\
\hline Firm A & $\begin{array}{l}\text { - In their remote service, they allow customers to } \\
\text { run their value-creating process without } \\
\text { disruption. }\end{array}$ & $\begin{array}{l}\text { - With already-installed robots, Firm A can offer } \\
\text { simulations and process optimizations in order to } \\
\text { improve productivity. Firm A also contributes with } \\
\text { knowledge to train the customer. }\end{array}$ \\
\hline Firm B & $\begin{array}{l}\text { - Industrial gas delivery services, based on } \\
\text { customer usage, prevented value-creating } \\
\text { process outages (laboratory, surgery, brewery or } \\
\text { otherprocesses with gas requirement). }\end{array}$ & $\begin{array}{l}\text { - Involved in the customer process directly to } \\
\text { support value creation, for example, in welding. }\end{array}$ \\
\hline Firm C & $\begin{array}{l}\text { - Preventive maintenance of the bearings during } \\
\text { planned stop enabled the customer in a pulp and } \\
\text { paper industry to not suffer unplanned } \\
\text { breakdowns. }\end{array}$ & $\begin{array}{l}\text { - Ongoing product and process support in their } \\
\text { customer's processes, including staff training as a } \\
\text { part of their program of operator-driven } \\
\text { reliability. }\end{array}$ \\
\hline Firm D & $\begin{array}{l}\text { Facilitated their customers' value creation } \\
\text { through maintenance of sensor-based } \\
\text { equipment. }\end{array}$ & $\begin{array}{l}\text { - Firm D's front-line employees worked together } \\
\text { with some customers in order to interpret the } \\
\text { data received from the sensors in order to plan } \\
\text { and optimize the usage of the handheld } \\
\text { machinery }\end{array}$ \\
\hline
\end{tabular}

\subsection{Summary and synthesis of discussion}

The thesis discusses the implications of an extended service innovation framework by including the realization phase and considering a service logic approach. The service innovation realization phase can be characterized by deployment and post-deployment phases where deployment emphasize the initial integration of resources from both firm and customer into the customer's process, and postdeployment emphasize the ongoing innovation process that solves customer problems over time through mutual integration of resources. Even if previous research in service innovation has emphasized delivery and implementation, it has been with an internal perspective that mainly considers the customer as a receiver (see, for example, de Brentani, 2001). This study denotes realization as part of service innovation with an active customer and emphasizes realization as the process where firm and customer together seek reciprocal ways to create value-in-use through integration of resources.

By emphasizing realization, service innovation becomes closer to customer value-in-use (Edvardsson \& Tronvoll, 2013; Rubalcaba, et al., 2012; Toivonen \& Siltaloppi, 2015). Having a deep knowledge of the customer's business and value creation is therefore central in order to support customer during service innovation realization (Lusch \& Nambisan, 2015), but also having a competent field service organization that typically is involved in deployment and post-deployment (Ulaga \& Reinartz, 2011). While previous research mainly has seen the field service organization as a delivery system that provides the services (de Brentani, 2001), this study emphasize that these experts need to be highly trained in order to understand the value proposition context (the customer's process), and also prepared to do adjustments to fit the customer's process. 
Accentuating service innovation realization and increasing incremental initiatives driven from the provider (for example field service organization), drives a managerial issue vis-à-vis coordinating with local initiatives and overall strategy. In order to coordinate and reproduce service innovation initiatives, the modular approach considers service element as part of a platform with resources that can be used for different customers and different needs. This study contributes to previous theory on modularity where customer resources not have been taken into consideration (See, for example, Bask, Lipponen, Rajahonka, \& Tinnilä, 2010, 2011; Rahikka, Ulkuniemi, \& Pekkarinen, 2011). Paper III emphasizes modularization and modular strategies and Paper $V$ develops a typology for interaction modes in service innovation.

Extending the service innovation framework with realization and integration of resources stemming from both provider and firm, an important niche of service innovation is productivity improvements that imply more efficient resource usage. Hence, improvements and practice-driven innovation (see, for example, Gallouj \& Weinstein, 1997, and Skålén et al., 2014) imply finding novel ways of conducting more resource-efficient processes in order to contribute to customer value creation, for example; increased operator efficiency, and reduced energy consumption.

Realization emphasizes interactions between the firm and the customer as the firm both directly and indirectly can influence the customer's value creation. Interaction modes depend on level of knowledge from both customer and firm; since the firm not necessarily possess all the resources nor knowledge themselves, it becomes important to also access complementary resources from the customers (Mustak, 2014). The analysis showed that different value propositions induced both indirect and direct interaction patterns. Therefore, understanding the capabilities of the customer is critical for the firm. 


\section{CONCLUSIONS, CONTRIBUTIONS AND FUTURE RESEARCH}

Together with the servitization of the economy, service innovation has evolved over time (Droege et al., 2009; Mele et al., 2014). This study contributes to the understanding of realization in service innovation by taking a service logic perspective to value creation that emphasizes value-in-use and interaction. This thesis concludes with insights on the characteristics of the realization phase and also interaction patterns and service productivity vis-á-vis realization.

\subsection{The extended service innovation framework}

The manufacturing firms in this study showed an approach to service innovation that was not limited to the development of the value propositions. Instead, an extensive approach that includes a range of activities that all aims to support the customer to create value associated from the value proposition could be seen. However, while extant research in service innovation has focused on service innovation as mainly a way to develop new value propositions (Droege et al., 2009; Froehle \& Roth, 2007), research has in many aspects foreseen the realization as an equal important part of the innovation process where the customer creates value-in-use related to the value proposition. Therefore, an extended framework of service innovation that includes realization is suggested in this study, and hence contributes to service innovation in manufacturing firms and service innovation literature with a service logic approach in particular (see for example: Edvardsson \& Tronvoll, 2013; 
Lusch \& Nambisan, 2015; Ordanini \& Parasuraman, 2011; Rubalcaba et al., 2010) by characterizing realization phase and analyzing different interaction patterns and how the firm can support the customer as a co-creator of value in realization part of service innovation.

The framework is inspired by service innovation scholars with a S-D logic approach (Edvardsson \& Tronvoll, 2013; Michel et al., 2008b), and suggests that realization is characterized by different activities that can be categorized as deployment and post-deployment, where deployment refers to the beginning of the customer's in-use with initial integration of firm's resources into the customer's sphere, and post-deployment to the continuous relationship that includes, for example, development of the customer's business. The conclusions herein are in line with research that sees the providers' ability to include customer experience in the service innovation process, together with an understanding of the customer's own ability, as essential (Möller et al., 2008).

Considering the realization phase, the expertise of the firm's field service organization becomes critical, which mandates the need for skilled experts that know the customer's process in addition to R\&D. The field service organization is not only a delivery system but instead highly trained experts who know the customer's process and goals. Emphasizing the expertise and the critical application of field service organization knowledge means that service innovation that starts from incremental initiatives in the realization process, becoming more frequent (see, for example, Skålén et al., 2014); hence, coordination becomes a topic for managers in order to manage service innovation. Here, service modularity is suggested as an approach for efficiency in coordination.

\subsection{Interaction patterns in realization process}

Considering an extended service innovation framework with a service logic, this thesis shows that, by seeing realization as an intertwined part of service innovation, firms can better control and directly influence the value that is created by the customer. The realization phase offers providers the opportunity not only to interact in real time with the customer and other stakeholders, but also to learn about customer needs for future value proposition development. However, realization also implies that firms need to better understand the context in which their customers are operating (Möller et al., 2008); otherwise, firms will have difficulties supporting them (Mathieu, 2001).

In paper $\mathrm{V}$, involvement in service innovation is suggested to consider both the customer's integration of resources in the firm's process, but also the firm's integration of resources in the customer's process. This approach contrasts with previous literature on interaction in service innovation that mainly focused on integrating and involving the customer in the firm's development process (Edvardsson et al., 2006). However, depending on their competence level, different customers may need greater or less support; a higher level of customer competence imply that the role of the firm can be that of facilitating the customer or discussing development and optimization of processes, while a lower level of customer competence imply that the firm needs to take a more extensive responsibility for the realization of service innovation and complement it with training of customers. In its facilitating role (indirect interaction), the firm's knowledge is primary directed against the offering and the process of integrating resources in the customer's process; however, in its co-creating role (direct interaction), the firm must also consider the customer's business process 
(for example, what the customer's customers require and how the their revenue mechanisms work. Hence, considering the complementarity of both resources and knowledge between firm and customer becomes critical in service innovation (Mustak, 2014).

The need for resources among non-firm actors and the related issues of how to access and combine and integrate them becomes critical when approaching service innovation and realization with a service logic (Rusanen et al., 2014). This thesis acknowledges the customer's own resources and knowledge as a central part of the resource integration for the service innovation process, especially when considering a service logic (Michel et al, 2008b). By specifying relevant resources in the service innovation process - both firm- and customer- related resources-this thesis contributes to a better understanding of how combined resources are deployed and coordinated. See Paper $V$ for more details.

\subsection{Understanding service productivity in realization part of service innovation}

Improving customer processes through a more efficient use of both firm and customer resources can contribute to value-in-use and hence be an approach to service innovation. For manufacturers that infuse service, it can be difficult to gain economic return (Gebauer et al., 2005); hence, a more efficient way of dealing with customer need variety is critical. This study recognizes service modularity as an enabler for more efficient service innovation as it divides activities and resources into elements that can be combined to meet different needs for several customers. Different service types require different modular strategies depending on the customer's role (active or passive) and the nature of the service process (rigid or fluid). For example, a service process with a passive customer and a rigid structure requires focus on internal efficiency and standardization. In contrast, an active customer and a fluid process requires a strategy focused on the relationship and understanding of customer processes (see Paper III). Also, Paper II suggests that offerings with a higher degree of customer participation are less susceptible to efficiency increases without at the same time affecting customer satisfaction; hence lean principles are primarily suggested for standardized offerings where customer participation is low.

\subsection{Theoretical contribution}

This study contributes to service innovation research in manufacturing firms and especially to the emerging literature stream in the intersection between service innovation and service logic (or S-D logic) (see for example Edvardsson \& Tronvoll, 2013; Lusch \& Nambisan, 2015; Michel et al, 2008a, b; Ordanini \& Parasuraman, 2011; Rubalcaba et al, 2012), by developing an extended service innovation framework that emphasizes realization. The thesis' main contributions are the increased understanding of 1) service innovation realization in manufacturing firms, 2) interactions in the realization phase of service innovation where the firm interacts with customers and other network actors to (co)-create value for customer, and 3 ) service productivity in service innovation realization exemplified through lean and service modularity.

Table 11 presents a summary of the theoretical contributions. 


\begin{tabular}{|c|c|c|c|}
\hline $\begin{array}{l}\text { Research } \\
\text { question }\end{array}$ & Theoretical findings & Contribution & Paper \\
\hline $\begin{array}{l}\text { What are the } \\
\text { main } \\
\text { characteristics of } \\
\text { the realization } \\
\text { part of service } \\
\text { innovation? }\end{array}$ & $\begin{array}{l}\text { Realization is seen as the part of } \\
\text { service innovation that relates to the } \\
\text { customer's creation of value-in-use } \\
\text { related to the value proposition, and } \\
\text { includes deployment and post- } \\
\text { deployment. } \\
\text { The process is characterized by the } \\
\text { firm's understanding of both technical } \\
\text { aspects of the service system as well } \\
\text { as business aspects for overall } \\
\text { customer revenue mechanisms. } \\
\text { Realization is both strategy-, } \\
\text { employee-, and customer-driven; } \\
\text { hence coordination from management } \\
\text { becomes an important task. }\end{array}$ & $\begin{array}{l}\text { A framework of the service } \\
\text { innovation process and, } \\
\text { especially, the realization } \\
\text { phase } \\
\text { Increased understanding of } \\
\text { how realization is related } \\
\text { to service innovation in } \\
\text { manufacturing firms }\end{array}$ & $\begin{array}{l}\text { Paper I,II, } \\
\text { III and V }\end{array}$ \\
\hline $\begin{array}{l}\text { How do firm and } \\
\text { customer } \\
\text { interact in service } \\
\text { innovation } \\
\text { realization? }\end{array}$ & $\begin{array}{l}\text { Customer and provider contribute } \\
\text { with different resources in different } \\
\text { degrees based on knowledge, skills } \\
\text { and resources. } \\
\text { Through direct interaction, the firm } \\
\text { can act as a co-creator in the service } \\
\text { innovation process, while through } \\
\text { indirect interaction, the firm can } \\
\text { facilitate the customer's value } \\
\text { creation in the service innovation } \\
\text { process. }\end{array}$ & $\begin{array}{l}\text { Framework that shows } \\
\text { what type of resources firm } \\
\text { and customer contribute in } \\
\text { service innovation (Paper } \\
\text { V) } \\
\text { Increased understanding } \\
\text { for interaction between } \\
\text { firm and customer in } \\
\text { service innovation } \\
\text { realization. }\end{array}$ & $\begin{array}{l}\text { Paper III, } \\
\text { IV, and V }\end{array}$ \\
\hline $\begin{array}{l}\text { How can service } \\
\text { productivity be } \\
\text { understood vis-à- } \\
\text { vis realization? }\end{array}$ & $\begin{array}{l}\text { Service productivity can be } \\
\text { understood as a service innovation } \\
\text { realization element as it can } \\
\text { contribute to improved customer } \\
\text { value through more efficient } \\
\text { resources usage. }\end{array}$ & $\begin{array}{l}\text { Through service } \\
\text { modularity, the firm can } \\
\text { increase its back office } \\
\text { efficiency, but } \\
\text { simultaneously respond to } \\
\text { a variety of needs. } \\
\text { Lean service provides an } \\
\text { opportunity to reduce use } \\
\text { of resources from both } \\
\text { firm and customer. }\end{array}$ & $\begin{array}{l}\text { Paper II, } \\
\text { III }\end{array}$ \\
\hline
\end{tabular}




\subsection{Managerial implications}

For managers that seek competitive advantages through service and service innovation in manufacturing, this thesis provides several implications. By using an extended service innovation framework, but also understanding and managing other network actors' resources, including knowhow and skills, managers can benefit from service innovation and support customers more efficiently.

Even though the traditional view of innovation is the process before the launch, managers should also cover the customer's value-creating process in order to provide input for future service innovation. By also being present in the phases after the launch, managers can more proactively and directly affect their customers' value-in-use through the front-line employees and field service organization. Of course, extending the service innovation framework affects how management must support their employees. For example, support tools in each of the service innovation phases are needed in order for employees to feel they have a rigorous support from the central firm. The support tools can include accessible data of the customer and how their business functions, as well as process data and historical logs that can support employees that work with delivering and deploying activities. Without the necessary competence of deploying the offering, and the ability to make proper adjustments, it will become difficult to succeed with this innovation approach. Therefore, establishing channels through which information can be shared is important. The firm needs to find ways to not only access general information, but also information of a more confidential nature in order to enable a deeper form of collaboration (Rusanen et al., 2014).

In order to manage service innovation realization, managers need to consider what actual knowledge is internal and what knowledge needs to be found from the customer or perhaps from the surrounding network. Problems connecting to other network resources are typically grounded in the difficulties of understanding the network (Ritter, Wilkinson, \& Johnston, 2004). However, evaluating internal resources and know-how can be a good starting point for management. By identifying areas where they have specific competence in the practical application of offerings, these areas can develop a platform for managers where they can strategically extend their innovation activities to also include realization. Without deep knowledge and understanding of the application of offerings, managers take a potential risk that can affect the firm negatively.

For managers who have intermediaries between them and the customer (for example, a dealer), the awareness of changing ties or building new ties will also affect the network. If management strengthens customer ties, then knowledge in how this affects both the ties between the firm and the intermediary, but also between the intermediary and the customer, is needed. Since intermediaries often play an important role in the supply chain, they must be treated more as a potential useful actor than an obstacle (Nordin, Brozovic, \& Holmlund, 2013). Communication training and other incentives can be ways to manage the network in order to keep good intermediary relationships and simultaneously developing customer ties. 


\subsection{Limitations and future research}

This study has focused on service innovation realization in manufacturing firms. Hence, describing and analyzing realization through important characteristics, productivity challenges, and interactions has contributed to theory. Even if customers and other external actors (dealers) have been interviewed, this study is limited by few interviews with customers. More empirical evidence would benefit research and also manufacturing firms. To study more in depth how customers interpret the collaboration with manufacturers that increasingly provide services can give insights into how a service innovation process can be formed. Also, this study is limited to manufacturing context, and therefore research that contributes with insights from other contexts would be valuable in order to better understand the service innovation process.

An interesting avenue for future research would be to find a theoretical alignment between service innovation and other related concepts of value creation, co-creation, and the development of value propositions. As service innovation increasingly focuses on creation of value for customers (Ostrom et al., 2010; Rubalcaba et al., 2012), alignment among the concepts is needed. For example, alignment in research has tended to evolve in the direction of widening of the offerings (models for developing offerings that include both services and products; e.g., den Hertog et al., 2010), while deepening of the offerings not has gained the same attention.

The empirical cases show that network actors are interconnected through social, economic, and technical ties. Since innovation in network includes intermediaries, customers, and other stakeholders, an interesting future research avenue would be to investigate how the different ties affect service innovation outcome and value creation, for example, if stronger ties between two actors can be related to specific service innovation outcome.

In the future, if manufacturing firm's transition towards service and increased interest in the customer's process continues, service innovation will rely on the ability to access resources across widespread actors and put them together to create customer value-in-use based on the diversity of customer needs. Hence, research that focus on how resource integration among network actors can contribute to value-in-use will be beneficial. 


\section{REFERENCES}

Alvesson, M. 2011. Intervjuer - Genomförande, tolkning och reflexivitet. Malmö: Liber AB.

Alvesson, M., \& Kärreman, D. 2011. Quality research and theory development. London: Sage.

Alvesson, M., \& Sköldberg, K. 2008. Tolkning och reflektion - vetenskapsfilosofi och kvalitativ metod. Lund: Studentlitteratur.

Alam, I. 2002. An exploratory investigation of user involvement in new service development. Journal of the Academy of Marketing Science, 30(3): 250-261.

Alam, I. 2006. Removing the fuzziness from the fuzzy front-end of service innovations through customer interactions. Industrial Marketing Management, 35(4): 468-480.

Alam, I., \& Perry, C. 2002. A customer-oriented new service development process. Journal of Services Marketing, 16(6): 515-534.

Anderson, E. W., Fornell, C., \& Rust, R. T. 1997. Customer Satisfaction, Productivity and Profitability: Differences between Goods and Services. Marketing Science, 16(2): 129-145.

Antioco, M., Moenaert, R. K., Lindgreen, A., \& Wetzels, M. G. M. 2008. Organizational antecedents to and consequences of service business orientations in manufacturing companies. Journal of the Academy of Marketing Science, 36(3): 337-358.

Ballantyne, D., \& Varey, R. J. 2006. Creating value-in-use through marketing interaction: the exchange logic of relating, communicating and knowing. Marketing theory, 6(3): 335-348. 
Barras, R. 1986. Towards a theory of innovation in services. Research Policy, 15(4): 161-173.

Bask, A., Lipponen, M., Rajahonka, M., \& Tinnilä, M. 2010. The concept of modularity. Journal of Manufacturing Technology, 21(3): 355-375.

Bask, A., Lipponen, M., Rajahonka, M., \& Tinnilä, M. 2011. Framework for modularity and customization: service perspective. Journal of Business \& Industrial Marketing, 26(5): 306319.

Berry, L. L., Parish, J. T., Cadwallader, S., Shankar, V., \& Dotzel, T. 2006. Creating new markets through service innovation. MIT Sloan Management Review, 47(2): 56-63.

Bessant, J., \& Davies, A. 2007. Managing service innovation, Innovation in Services (DTI Occasional Paper No. 9, June 2007): 61-95: Department of Trade and Industry, UK.

Bettencourt, L., Brown, S., \& Sirianni, N. 2012. The secret to true service innovation. Business Horizons.

Bledow, R., Frese, M., Anderson, N., Erez, M., \& Farr, J. 2009. A dialectic perspective on innovation: Conflicting demands, multiple pathways, and ambidexterity. Industrial and Organizational Psychology, 2(3): 305-337.

Bowen, D.E., \& Youngdahl, W.E. 1998. "Lean" service: in defense of a production-line approach", International Journal of Service Industry Management, 9(3): 207-225.

Brady, T., Davies, A., \& Gann, D. 2005. Creating value by delivering integrated solutions. International Journal of Project Management, 23(5): 360-365.

Brax, S. 2005. A manufacturer becoming service provider - challanges and a paradox. Managing Service Quality, 15(2): 142-155.

Böttcher, M. and Klingner, S. 2011. Providing a method for composing modular B2B services, Journal of Business \& Industrial Marketing, 26(5): 320-331.

Carlborg, P., Kindström, D., \& Kowalkowski, C. 2014. The evolution of service innovation research: a critical review and synthesis. The Service Industries Journal, 34(5): 373-398.

Coombs, R., \& Miles, I. 2000. Innovation, measurement and dervices: The new problematique. In J. S. Metcalfe \& I. Miles (Eds.), Innovation systems in the service economy, measurement and case study analysis (pp. 85-103). Boston: Kluwer Academic.

Cova, B., \& Salle, R. 2008. Marketing solutions in accordance with the S-D logic: Co-creating value with customer network actors. Industrial Marketing Management, 37(3): 270-277.

Davies, A. 2004. Moving base into high-value integrated solutions: a value stream approach. Industrial and Corporate Change, 13(5): 727-756.

Davies, A., Brady, T., \& Hobday, M. 2007. Organizing for solutions: Systems seller vs. systems integrator. Industrial Marketing Management, 36(2): 183-193.

de Brentani, U. 2001. Innovative versus incremental new business services: different keys for achieving success. Journal of Product Innovation Management, 18: 169-187.

de Souza, B.L. 2009. Trends and approaches in lean healthcare. Leadership in Health Services, 22(2): 121-139.

de Vries, E. J. 2006. Innovation in services in networks of organizations and in the distribution of services. Research Policy, 35(7): 1037-1051.

den Hertog, P., van der Aa, W., \& de Jong, M. W. 2010. Capabilities for managing service innovation: towards a conceptual framework. Journal of Service Management, 21(4): 490-514.

Djellal, F. \& Gallouj, F. 2010. Beyond productivity strategies in services. Journal of Innovation Economics, 1: 89-104.

Drejer, I. 2004. Identifying innovation in surveys of services: a Schumpeterian perspective. Research Policy, 33(3): 551-562.

Droege, H., Hildebrand, D., \& Forcada, M. A. H. 2009. Innovation in services: present findings, and future pathways. Journal of Service Management, 20(2): 131-155.

Dubois, A., \& Araujo, L. 2007. Case research in purchasing and supply management: opportunities and challenges. Journal of Purchasing and Supply Management, 13(3): 170-181. 
Dubois, A., \& Gadde, L.-E. 2002. Systematic combining: an abductive approach to case research. Journal of Business Research, 55(7): 553-560.

Dubois, A., \& Gibbert, M. 2010. From complexity to transparency: managing the interplay between theory, method and empirical phenomena in IMM case studies. Industrial Marketing Management, 39(1): 129-136.

Dörner, N., Gassmann, O., \& Gebauer, H. 2011. Service innovation: why is it so difficult to accomplish? Journal of Business Strategy, 32(3): 37-46.

Edvardsson, B. 1997. Quality in new service development: Key concepts and a frame of reference. International Journal of Production Economics, 52(1/2): 31-46.

Edvardsson, B., Gustafsson, A., Kristensson, P., Magnusson, P., \& Matthing, J. 2006. Involving Customers in New Service Development. London, UK: Imperial College Press.

Edvardsson, B., Kristensson, P., Magnusson, P. R., \& Sundström, E. 2012. Customer integration within service development-A review of methods and an analysis of insitu and exsitu contributions. Technovation, 32: 419-429.

Edvardsson, B., \& Olsson, J. 1996. Key concepts for new service development. Service Industries Journal, 16(2): 140-164.

Edvardsson, B., \& Tronvoll, B. 2013. A new conceptualization of service innovation grounded in S-D logic and service systems. International Journal of Quality and Service Sciences, 5(1): 19-31.

Eggert, A., Hogreve, J., Ulaga, W., \& Muenkhoff, E. 2013. Revenue and Profit Implications of Industrial Service Strategies. Journal of Service Research.

Eisenhardt, K. M. 1989. Building Theory from Case Study Research. Academy of Management Review, 14(4): 532-550.

Eisenhardt, K. M., \& Graebner, M. E. 2007. Theory building from cases: Opportunities and challenges. Academy of Management Journal, 50(1): 25-32.

Ettlie, J. E., \& Rosenthal, S. R. 2011. Service versus Manufacturing Innovation. Journal of Product Innovation Management, 28: 285-299.

Fang, E. 2008. Customer Participation and the Trade-Off Between New Product Innovativeness and Speed to Market. Journal of Marketing, 72(4): 90-104.

Fang, E., Palmatier, R. W., \& Steenkamp, J.-B. E. M. 2008. Effect of Service Transition Strategies on Firm Value. Journal of Marketing, 72(September): 1-14.

Fisk, R. P., Brown, S. W., \& Bitner, M. J. 1993. Tracking the evolution of the services marketing literature. Journal of Retailing, 69(Spring): 61-103.

Fitzsimmons, J., \& Fitzsimmons, M. J. 1999. New service development: creating memorable experiences: Sage Publications.

Froehle, C. M., \& Roth, A. V. 2007. A resource-process framework of new service development. Production and Operations Management, 16(2): 169-188.

Frow, P., McColl-Kennedy, J. R., Hilton, T., Davidson, A., Payne, A., \& Brozovic, D. 2014. Value propositions A service ecosystems perspective. Marketing Theory: 1470593114534346.

Fuglsang, L., \& Sundbo, J. 2005. The organizational innovation system: Three modes. Journal of Change Management, 5: 329-344.

Gallouj, F. 1998. Innovating in reverse: services and the reverse product cycle. European Journal of Innovation Management, 1(3): 123-138.

Gallouj, F. 2002. Innovation in services and the attendance old and new myths. Journal of SocioEconomics, 31(2): 137.

Gallouj, F., \& Djellal, F. 2011. The handbook of innovation and services: a multi-disciplinary perspective: Edward Elgar Publishing.

Gallouj, F., \& Savona, M. 2009. Innovation in services: a review of the debate and a research agenda. Journal of Evolutionary Economics, 19(sept): 149-172.

Gallouj, F., \& Weinstein, O. 1997. Innovation in services. Research Policy, 26(4/5): 537-556. 
Gallouj, F., \& Windrum, P. 2009. Services and serivces innovation. Journal of Evolutionary Economics, 19(2): 141-148.

Garcia, R., \& Calantone, R. 2002. A critical look at technological innovation typology and innovativeness terminology: a literature review. Journal of Product Innovation Management, 19(2): 110-132.

Gebauer, H., Edvardsson, B., Gustafsson, A., \& Witell, L. 2010. Match or mismatch: Strategy-structure configurations in the service business of manufacturing companies. Journal of Service Research, 13(2): 198-215.

Gebauer, H., Fleisch, E., \& Friedli, T. 2005. Overcoming the Service Paradox in Manufacturing Companies. European Management Journal, 23(1): 14-26.

Gebauer, H., Gustafsson, A., \& Witell, L. 2011. Competitive advantage through service differentiation by manufacturing companies. Journal of Business Research, 64(12): 1270-1280.

Gebauer, H., Krempl, R., Fleisch, E., \& Friedli, T. 2008. Innovation in product-related services. Managing Service Quality, 18(4): 387-404.

Gebauer, H., Paiola, M., \& Saccani, N. 2013. Characterizing service networks for moving from products to solutions. Industrial Marketing Management, 42(1):31-46.

Gebauer, H., Ren, G.-J., Valtakoski, A., \& Reynoso, J. 2012. Service-driven manufacturing: provision, evolution and financial impact of services in industrial firms. Journal of Service Management, 23(1): 120-136.

Geum, Y., Shin, J., \& Park, Y. 2011. FMEA-based portfolio approach to service productivity improvement. Service Industries Journal. 31(11): 1825-1847.

Gibbert, M., Ruigrok, W., \& Wicki, B. 2008. What passes as a rigorous case study? Strategic Management Journal, 29(13): 1465-1474.

Glaser, B. G., \& Strauss, A. L. 1967. The Discovery of Grounded Theory: Strategies of Qualitative Research. London, UK: Wiedenfeld \& Nicholson.

Gremyr, I., Löfberg, N., \& Witell, L. 2010. Service innovations in manufacturing firms. Managing Service Quality, 20(2): 161-175.

Gremyr, I., Witell, L., Löfberg, N., Edvardsson, B., \& Fundin, A. 2014. Understanding new service development and service innovation through innovation modes. Journal of Business \& Industrial Marketing, 29(2): 123-131.

Grönroos, C. 2007. Service Management and Marketing - Customer Management in Service Competition (3rd ed.). Chichester, UK: John Wiley \& Sons Ltd.

Grönroos, C. 2011. Value co-creation in service logic: A critical analysis. Marketing theory, 11(3): 279301.

Grönroos, C., \& Gummerus, J. 2014. The service revolution and its marketing implications: service logic vs service-dominant logic. Managing Service Quality, 24(3): 206-229.

Grönroos, C., \& Ravald, A. 2011. Service as business logic: implications for value creation and marketing. Journal of Service Management, 22(1): 5-22.

Grönroos, C., \& Voima, P. 2013. Critical service logic: making sense of value creation and co-creation. Journal of the Academy of Marketing Science, 41(2): 133-150.

Gummesson, E. 2005. Qualitative research in marketing: Road-map for a wilderness of complexity and undpredictability. European Journal of Marketing, 39(3/4): 309-327.

Halinen, A., \& Törnroos, J.-Å. 2005. Using case methods in the study of contemporary business networks. Journal of Business Research, 58: 1287-1297.

Hargrave, T. J., \& Van de Ven, A. H. 2006. A collective action model of institutional innovation. Academy of Management Review, 31(4): 864-888.

Hauser, J., Tellis, G., \& Griffin, A. 2006. Research on inovation and new peoducts: a review and agenda for marketing science. Marketing Science, 25(6): 687-717.

Heinonen, K., Strandvik, T., Mickelsson, K. J., Edvardsson, B., Sundström, E., \& Andersson, P. 2010. A customer-dominant logic of service. Journal of Service Management, 21(4): 531-548. 
Heinonen, K., Strandvik, T., \& Voima, P. 2013. Customer dominant value formation in service. European Business Review, 25(2): 104-123.

Holmlund, M., \& Törnroos, J.-Å. 1997. What are relationships in business networks? Management Decision, 35(4): 304-309.

Håkansson, H. \& Ford, D. 2002. How should companies interact in business networks? Journal of Business Research, 55(2): 133-139.

Jacob, F., \& Ulaga, W. 2008. The transition from product to service in business markets: An agenda for academic inquiry. Industrial Marketing Management, 37(3): 247-253.

James-Moore, S.M. \& Gibbons, A. 1997. Is lean manufacture universally relevant? An investigative methodology, International Journal of Operations and Production Management, 17(9): 899-911.

Johnston, R., \& Jones, P. 2004. Service productivity: Towards understanding the relationship between operational and customer productivity. International Journal of Productivity and Performance Management, 53(3): 201-213.

Jong, J. \& Vermeulen, P. 2003. Organizing successful new service development: a literature review. Management Decision. 41(9): 844-858.

Järvensivu, T., \& Törnroos, J.-Å. 2010. Case study research with moderate constructionism: Conceptualization and practical illustration. Industrial Marketing Management, 39(1): 100108.

Kindström, D. 2010. Towards a service-based business model - Key aspects for future competitive advantage. European Management Journal, 28: 479-490.

Kindström, D., \& Kowalkowski, C. 2009. Development of industrial service offerings - A process framework. Journal of Service Management, 20(2): 156-172.

Kjellberg, H., Azimont, F., \& Reid, E. 2015. Market innovation processes: Balancing stability and change. Industrial Marketing Management, 44(0): 4-12.

Korhonen, H. M. 2014. Widening the Perspective on Industrial Innovation: A Service-Dominant-Logic Approach. Technology Innovation Management Review, 4(5).

Kostecki, M. M. 1993. Marketing strategies for services: Globalization, client-orientation, deregulation: Pergamon Press.

Kowalkowski, C., Kindström, D., \& Brehmer, P.-O. 2009. Managing industrial service offerings in global business markets. Journal of Business \& Industrial Marketing, accepted for publication.

Kristensson, P., Gustafsson, A., \& Witell, L. 2014. Tjänsteinnovation (1 ed.). Lund: Studentlitteratur $A B$.

Kuusisto, J., Kuusisto, A., \& Yli-Viitala, P. 2013. Service development tools in action. The Service Industries Journal, 33(3-4): 352-365.

Landsbergis, P.A., Cahill, J. \& Schnall, P. 1999. The impact of lean production and related new systems of work organization on worker health, Journal of Occupational Health Psychology, 4(2): 108-130.

Langley, A. 1999. Strategies for Theorizing from Process Data. The Academy of Management Review, 24(4): 691-710.

Larsson, R. \& Bowen, D.E. 1989. Organization and customer: managing design and coordination of services, Academy of Management Review, 14(2): 213-233.

Lehmann, D.R., \& McAlister, R. (2011). Sophistication in research in marketing. Journal of Marketing, 75(July), 155-165.

Levitt, T. 1969. The Marketing Mode. New York, NY: McGraw-Hill.

Lindberg, N., \& Nordin, F. 2008. From products to services and back again: Towards a new service procurement logic. Industrial Marketing Management, 37(3): 292-300. 
Lindgreen, A., Antioco, M., Palmer, R., \& van Heesch, T. 2009. High-tech, innovative products: identifying and meeting business customers' value needs. Journal of Business \& Industrial Marketing, 24(3/4): 182-197.

Lusch, R. F., \& Nambisan, S. 2015. Service innovation: A service-dominant logic perspective. MIS Quarterly, 39(1): 155-175.

Lusch, R. F., Vargo, S. L., \& O'Brien, M. 2007. Competing through service: Insights from servicedominant logic. Journal of Retailing, 83(1): 5-18.

Lusch, R. F., Vargo, S. L., \& O'Brien, M. 2007. Competing through service: Insights from servicedominant logic. Journal of Retailing, 83(1): 5-18.

Lusch, R. F., Vargo, S. L., \& Tanniru, M. 2010. Service, value networks and learning. Journal of the Academy of Marketing Science, 38(1): 19-31.

Macinnis, D. J. 2011. A framework for conceptual contributions in marketing. Journal of Marketing, 75(July): 136-154.

Maglio, P. P., Vargo, S. L., Caswell, N., \& Spohrer, J. 2009. The service system is the basic abstraction of service science. Information Systems and e-business Management, 7(4): 395-406.

Magnusson, P. R. 2003. Benefits of involving users in service innovation. European Journal of Innovation Management, 6(4): 228-238.

Magnusson, P. R., Matthing, J., \& Kristensson, P. 2003. Managing user involvement in service innovation experiments with innovating end users. Journal of Service Research, 6(2): 111124.

Maroto-Sánchez, A. 2012. Productivity in the services sector: conventional and current explanations. The Service Industries Journal, 32(5): 719-746.

Mathieu, V. 2001. Product services: from a service supporting the product to a service supporting the client. Journal of Business \& Industrial Marketing, 16(1): 39-61.

Matthing, J., Sanden, B., \& Edvardsson, B. 2004. New service development: learning from and with customers. International Journal of Service Industry Management, 15(5): 479-498.

Matthyssens, P., \& Vandenbempt, K. 2008. Moving from basic offerings to value-added solutions: Strategies, barriers and alignment. Industrial Marketing Management, 37(3): 316-328.

Mele, C., Colurcio, M., \& Russo-Spena, T. 2014. Research traditions of innovation: Goods-dominant logic, the resource-based approach, and service-dominant logic. Managing Service Quality, 24(6): 612-642.

Michel, S., Brown, S., \& Gallan, A. S. 2008a. Service-logic innovations: how to innovate customers, not products. California Management Review, 50(3): 49-65.

Michel, S., Brown, S. W., \& Gallan, A. S. 2008b. An expanded and strategic view of discontinuous innovations: deploying a service-dominant logic. Journal of the Academy of Marketing Science, 36(1): 54-66.

Miles, I. 1993. Services in the new industrial economy. Futures, 25(6): 653-672.

Moorman, C., \& Rust, R. T. 1999. The role of marketing. The Journal of Marketing: 180-197.

Mumford, M. D., Scott, G. M., Gaddis, B., \& Strange, J. M. 2002. Leading creative people: Orchestrating expertise and relationships. The Leadership Quarterly, 13(6): 705-750.

Mustak, M. 2014. Service innovation in networks: a systematic review and implications for businessto-business service innovation research. Journal of Business \& Industrial Marketing, 29(2): 151-163.

Möller, K., Rajala, R., \& Westerlund, M. 2008. Service innovation myopia: a new recipe for clientprovider value creation. California Management Review, 50(3): 31-48.

Neely, A. 2008. Exploring the financial consequences of the servitization of manufacturing. Operations Management Research, 1(2), 103-118.

Neu, W. A., \& Brown, S. W. 2005. Forming successful business-to-business services in goodsdominant firms. Journal of Service Research, 8(1): 3-17. 
Ng, I. C. L., \& Smith, L. 2012. An integrative framework of value. Review of Marketing Research, 9: 207-243.

Nijssen, E. J., Hillebrand, B., Vermeulen, P. A. M., \& Kemp, R. G. M. 2006. Exploring product and service innovation similarities and differences. International Journal of Research in Marketing, 23(3): 241-251.

Noordhoff, C., Kyriakopoulos, K., Moorman, C., Pauwels, P., \& Dellaert, B. G. C. 2011. The Bright Side and Dark Side of Embedded Ties in Business-to-Business Innovation. Journal of Marketing, 75(5): 34-52.

Nordin, F., Brozovic, D., \& Holmlund, M. 2013. Disintermediation in Business-to-Business Service Channels: Mechanisms and Challenges. Journal of Business-to-Business Marketing, 20(4): 179-192.

Nordin, F. \& Kowalkowski, C. 2010. Solutions offerings: A critical review and reconceptualisation. Journal of Service Management, 21(4): 441-459.

Normann, R. 2001. Reframing Business - When the Map Changes the Landscape (First ed.). Chichester, UK: John Wiley \& Sons, Ltd.

Normann, R. \& Ramirez, R. 1993. From value chain to value constellation: Designing interactive strategy. Harvard Business Review, 71(4):65-77.

Nuutinen, M., \& Ojasalo, K. 2014. Enhancing service innovation in a business-to-business context: Four questions for SMEs transforming to service logic. International Journal of Quality and Service Sciences, 6(4): 290-308.

Oliva, R., \& Kallenberg, R. 2003. Managing the transition from products to services. International Journal of Service Industry Management, 14(2): 160-172.

Ordanini, A., \& Parasuraman, A. 2011. Service innovation viewed through a service-dominant logic lens: a conceptual framework and empirical analysis. Journal of Service Research, 14(1): 323.

Ostrom, A. L., Bitner, M. J., Brown, S. W., Burkhard, K. A., Goul, M., Smith-Daniels, V., Demirkan, H., \& Rabinovich, E. 2010. Moving forward and making a difference: Research priorities for the science of service. Journal of Service Research, 13(1): 4-36.

Parasuraman, A. 2002. Service quality and productivity: A synergistic perspective. Managing Service Quality, 12(1): 6-9.

Pekkarinen, S., \& Ulkuniemi, P. 2008. Modularity in developing business services by platform approach. The International Journal of Logistics Management. 19(1): 84-103.

Penttinen, E., \& Palmer, J. 2007. Improving firm positioning through enhanced offerings and buyerseller relationships. Industrial Marketing Management, 36(5): 552-564.

Perks, H., Gruber, T., \& Edvardsson, B. 2012. Co-creation in radical service innovation: a systematic analysis of microlevel processes. Journal of Product Innovation Management, 29(6): 935951.

Quinn, J. B. 1992. Intelligent Enterprise: A Knowledge and Service Based Paradigm for Industr: Simon and Schuster.

Rahikka, E., Ulkuniemi, P., \& Pekkarinen, S. 2011. Developing the value perception of the business customer through service modularity. Journal of Business \& Industrial Marketing, 26(5): 357-367.

Ravald, A., \& Grönroos, C. 1996. The value concept and relationship marketing. European Journal of Marketing, 30(2):19-30.

Ritter, T., Wilkinson, I. F., \& Johnston, W. J. 2004. Managing in complex business networks. Industrial Marketing Mangement, 33(3): 175-183.

Rubalcaba, L., Michel, S., Sundbo, J., Brown, S. W., \& Reynoso, J. 2012. Shaping, organizing, and rethinking service innovation: a multidimensional framework. Journal of Service Management, 23(5): 696-715. 
Rusanen, H., Halinen, A., \& Jaakkola, E. 2014. Accessing resources for service innovation - the critical role of network relationships. Journal of Service Management, 25(1).

Rust, R. T., \& Huang, M.-H. 2012. Optimizing Service Productivity. Journal of Marketing, 76(March): 47-66.

Rust, R.T., \& Thompson, D.V. 2006. How does marketing strategy change in a service-based world? Implications and directions for research. In R.F. Lusch \& A.L. Vargo (Eds.), The service-dominant logic of marketing: Dialog, debate, and directions (pp. 381-392). Armonk, NY: M.E. Shape.

Salonen, A. 2011. Service transition strategies of industrial manufacturers. Industrial Marketing Management, 40(5): 683-690.

Santamaría, L., Nieto, M. J., \& Miles, I. 2012. Service innovation in manufacturing firms: Evidence from Spain. Technovation, 32(2), 144-155.

Sawhney, M. 2006. Going beyond the product: Defining, designing, and delivering customer solutions. In R. F. Lusch, \& S. L. Vargo (Eds.), The Service-Dominant Logic of Marketing: Dialog, Debate, and Directions, First ed.: 365-380. Armonk, NY: M. E. Shape.

Scheuing, E. E., \& Johnson, E. M. 1989. A proposed model for new service development. Journal of Services Marketing, 3(2): 25-34.

Shah, R., \& Ward, P. T. 2007. Defining and developing measures of lean production. Journal of Operations Management, 25(4): 785-805.

Shostack, G. L. 1977. Breaking Free from Product Marketing. Journal of Marketing, 41(April): 73-80.

Siltaloppi, J., \& Toivonen, M. 2015. Integration of planning and execution in service innovation. The Service Industries Journal, 35(4): 197-216.

Singh Panesar, S., \& Markeset, T. 2008. Development of a framework for industrial service innovation management and coordination. Journal of Quality in Maintenance Engineering, 14(2): 177193.

Skålén, P., Gummerus, J., von Koskull, C., \& Magnusson, P. 2014. Exploring value propositions and service innovation: a service-dominant logic study. Journal of the Academy of Marketing Science: $1-22$.

Song, L. Z., Song, M., \& Di Benedetto, C. A. 2009. A Staged Service Innovation Model*. Decision Sciences, 40(3): 571-599.

Spohrer, J., Vargo, S. L., Caswell, N., \& Maglio, P. P. 2008. The Service System is the Basic Abstraction of Service Science Paper presented at the 41st Hawaii International Conference on System Sciences, Hawaii.

Spring, M., \& Araujo, L. 2013. Beyond the service factory: service innovation in manufacturing supply networks. Industrial Marketing Management, 42(1): 59-70.

Storbacka, K. 2011. A solution business model: Capabilities and management practices for integrated solutions. Industrial Marketing Management, 40(5): 699-711.

Strandvik, T., Holmlund, M., \& Edvardsson, B. 2012. Customer needing: a challenge for the seller offering. Journal of Business \& Industrial Marketing, 27(2): 132-141.

Sundbo, J. 1997. Management of Innovation in Services. Service Industries Journal, 17(3): 432-455.

Sundbo, J. 2002. The service economy: Standardization or customization?. Service Industries Journal, 22(4): 93-116.

Sundbo, J., \& Gallouj, F. 2000. Innovation as a loosely coupled system in services. International Journal of Services Technology and Management, vol. 1: 15-36.

Toivonen, M., \& Tuominen, T. 2009. Emergence of innovations in services. Service Industries Journal, 29(7): 887-902.

Tranfield, D., Denyer, D., \& Smart, P. 2003. Towards a methodology for developing evidence-informed management knowledge by means of systematic review. British journal of management, 14(3): 207-222. 
Tuli, K. R., Kohli, A. K., \& Bharadwaj, S. G. 2007. Rethinking Customer Solutions: From Product Bundles to Relational Processes. Journal of Marketing, 71(July): 1-17.

Ulaga, W., \& Reinartz, W. 2011. Hybrid offerings: How manufacturing firms combine goods and services successfully. Journal of Marketing, 75(November): 5-23.

Utterback, J. M., \& Abernathy, W. J. 1975. A dynamic model of process and product innovation. Omega, 3(6): 639-656.

Van de Ven, A. H., \& Johnson, P. E. 2006. Knowledge for theory and practice. Academy of management review, 31(4): 802-821.

Vandermerwe, S. 1994. Quality in services: The 'softer' side is 'harder' (and smarter). Long Range Planning, 27(2): 45-56.

Vargo, S. L. 2008. Customer Integration and Value Creation: Paradigmatic Traps and Perspectives. Journal of Service Research, 11(2): 211-215.

Vargo, S. L. 2011. On marketing theory and service-dominant logic: Connecting some dots. Marketing Theory, 11(1): 3-8.

Vargo, S. L., \& Lusch, R. F. 2004. Evolving to a New Dominant Logic for Marketing. Journal of Marketing, 68(January): 1-17.

Vargo, S. L., \& Lusch, R. F. 2008. Service-dominant logic: continuing the evolution. Journal of the Academy of Marketing Science, 36(1): 1-10.

Vargo, S. L., Wieland, H., \& Akaka, M. A. 2015. Innovation through institutionalization: A service ecosystems perspective. Industrial Marketing Management, 44(0): 63-72.

Weick, K. E. 1989. Theory construction as disciplined imagination. Academy of Management Review, 14: 516-531.

Windahl, C. \& Lakemond, N. 2010. Integrated solutions from a service-centered perspective: Applicability and limitations in the capital goods industry. Industrial Marketing Management, 39(8): 1278-1290.

Witell, L., \& Löfgren, M. 2013. From service for free to service for fee: business model innovation in manufacturing firms. Journal of Service Management, 24(5): 4-4.

Yin, R. K. 2009. Case study research: design and methods (4 ed.). Thousand Oaks: Sage Inc.

Womack, J. P., Jones, D. T., \& Roos, D. 1990. The Machine that changed the world: The story of lean production. New York, NY: Rawson Associates. 



\section{Articles}

The articles associated with this thesis have been removed for copyright reasons. For more details about these see:

http://urn.kb.se/resolve?urn=urn:nbn:se:liu:diva-117965 